\title{
REORDERED PUBLICS: Re-imagining the City of London
}

\section{ABSTRACT}

The unrelenting global recession has intensified pressure on the public realm to mediate between different actors vying to assert political rights, economic claims, and social expression. Multi-disciplinary frameworks for reading economic systems as integral to the design and lived experience of the public realm have shaped our conceptualisation of the financial crisis as a city design problem. The following body of work offers a sociospatial and political analysis of the City of London as a 'business as usual' city in which private interests trump public good. Through a design-based proposal for policy intervention and physical restructuring that radically alters the City's socio-spatial realities, we re-imagine the City of London as a true public city for the 21 st century. Where productivity stems from the residential diversity, urban intensity and inclusive public spaces that significantly increasing residential numbers in the City brings.

\section{KEYWORDS}

City of London; Housing; Public City; Public Space; Neoliberal City; Design Intervention; Occupy.

\section{INTRODUCTION}

In the late summer and autumn of 2011, London was a city strained by economic recession, unhinged by a wave of riots, and occupied by demands for alternatives to austerity. The public presented a series of challenges to 'business as usual.' On August 6th, the protest against the police killing of a young black man in North London escalated into attacks on businesses and public infrastructure that ignited five days of riots across London and the UK (Guardian and the London 
School of Economics, 2011). On the morning of October 15th, protesters aligned with the global Occupy Movement stormed the London Stock Exchange - a symbolic heart of the local and global financial sector (Occupy LSX, 2011). Forced by police to retreat, protesters established a makeshift tent city along the steps of St. Paul's Cathedral, where they set up temporary residences, educational programmes, and political working groups (ibid). Similar scenes unfolded in over 2,500 cities around the world, where the ad-hoc public city embedded itself in the crevices of the business city (Occupy Together, 2011). In London, Occupy Camps appropriated pavements, parks, and vacant office buildings near the very institutions they deemed accountable for job losses, home evictions, and widening income disparities. Converting 8-hour business districts into palpable public sites of 24-7 civic performance, London's camps spatialised democratic ideals in the everyday non-spaces typically occupied by hurried commuters and symbols of corporate power.

The City of London - a leading global business enclave with a dedicated police force and a small residential population of 9,000 - responded to events with increased securitisation, legal action, and unyielding historic ceremony. During the 5 days of riots, the City's private alert system broadcasted over 100,000 messages to businesses and residents, advising them on how to respond to the events (Vocal, 2011). Although no rioting occurred within the City's boundaries, companies urged employees to avoid public transportation and to work from home, bank branches and retailers were closed to the public, and the City's police force remained on emergency alert (City of London Police, n.d.). Despite the presence of the Occupy camp at St. Paul's, the Lord Mayor's parade held to the same 785-year-old route through the City, promenading livery companies, military bands, and police teams past the protesters. In February 2012, the 
Corporation of the City of London secured the legal right to evict the St. Paul's camp, winning a court case on the premise that the 24-7 presence of protesters obstructed businesses and threatened 'public health and safety' (Davies, 2012).

The context of the current financial crisis has intensified pressure on the public realm to mediate between different actors vying to assert political rights, economic claims, and social expression. Although the August 2011 riots and the Occupy movement emerged from distinct socio-economic and political conditions, both illustrate how the control of public space becomes an increasingly valuable asset in a time of crisis. Sociologist Craig Calhoun extends the implications of the 2008 financial crisis beyond the market, positing, "the crisis does not just belong to the financial rating agencies, Goldman Sachs, or other corporations. It belongs to culture and society" (van der Haak, 2011). Architect Laura Burkhalter and sociologist Manuel Castells frame the financial crisis as a failure of both neoliberal market systems and their translations into urban form, declaring that the "bankruptcy of the economic and spatial model" should be addressed equally through urban design and political reforms (Burkhalter and Castells, 2009: 24). These multidisciplinary frameworks for reading economic systems as integral to the design and lived experience of the public realm have shaped our conceptualisation of the financial crisis as a city design problem.

$<$ FIGURE 1 (large)>

Our investigation into the City occurs in a post-Occupy, post-financial crisis moment. As part of the City Design and Social Science Master's course at the London School of Economics, we came together as a studio group to explore the possibilities of a new public realm in the City of London. As an interdisciplinary group of architects, urban 
researchers and sociologists, we worked over the course of six months on extensive site research, observing the current uses of public and private realms, from plazas and transit nodes to trading desks and pubs, and then formulating a strategy for intervention.

Conceptually, we framed our intervention by scanning the complexities of public space in the City, which led us to an exploration of key global protest movements since 2010. We interrogated the notion of the 'world city' (read 'neoliberal city') and its inherent flaws. Ultimately our intervention is enacted through both a policy-based and spatial reimagination of the City of London and the kindred business districts of other 'world cities.'

The Occupy Movement demonstrated the inextricable link between politics and the polis and presented an alternative geography (Bolton, Froese and Jeffrey, 2013). "OWS [Occupy Wall Street] understands that to call into being a fairer, more democratic, just, and equitable world they cannot rely on the infrastructure of neoliberal capitalism, but that they must build an alternative: one that commons, builds and enlivens the public square. In these terms, space [...] is constituted as a central medium through which transformative politics may be imagined" (ibid: 154). Drawing on the radical imagination of the city demonstrated by Occupy, particularly its 'by people for people' message connects a utopian desire to pragmatic planning theory through the notion of 'integral urbanism' developed by Nan Ellin (2006).

Ellin defines integral urbanism as not aiming to create deterministic master plans, but instead allowing processes to unfold (2006). Specifically she states that planning or urban spatial interventions should be, "[...] arrived at intuitively as well as rationally. They are inspired by physical as well as social and historical context. In contrast to conventional 
planning, these interventions are not always developed and represented primarily in plan and section. Rather, they might be conveyed through imagery suggesting the latent experiential quality that the intervention would activate" (2006: 10). We thus apply Ellin's concept of 'integral urbanism' as a useful device through which to express this design driven, and imaginary analysis of a post-Occupy City of London and its future.

Occupy occurred at a global moment in which exclusive economic enclaves were being challenged in cities around the world. We began our investigation of the 'public city' in the City of London at this moment of crisis and contradiction, and very little has since changed: banks continue to rely on public bailouts as public institutions experience funding cuts; businesses have more votes than residents and women are restricted from participating in certain political processes (Fig. 2); public demonstrations are treated as security threats and public security is outsourced to private companies (Vocal, 2011). In this context, we continue to ask: What is the 'public city' and what role can it play in addressing urban inequality? "The occupation unlocked the creative, radical imagination" (Premo quoted in Gupta, 2012), and we propose the creation of a more public City of London, in which productivity stems from diversity and intensity, and public spaces facilitate inclusion and opportunity. The City of London is unique, yet it is also kin to a global family of urban business districts. It offers an opportunity to question the efficiency of urban terrain ruled by private interests and to reconceptualise the 'business as usual' city as a true public city for the twenty-first century.

$<$ FIGURE 2 (small) $>$ 


\section{PART 1: CONTEXT}

\section{A Climate of Occupation}

"Occupy W all Street started as an idea, emerged through the power of the people, was dismantled by the state through coordinated evictions, and is now bubbling beneath the surface of a world where our communities and workplaces are dominated by a system that puts profits before people and democracy" (Grim, 2013).

At the end of 2010, a Tunisian vegetable salesman set fire to himself in protest over the heavy-handedness of police. His actions sparked the start of the Arab Spring that has ignited regime changes in Tunisia, Egypt and Libya, and the ongoing battle for change in Syria (Blight et al., 2011). The literal occupation of Tahrir Square in central Cairo inspired the emergence of similar protest camps in other Arab Spring cities. The symbolic occupation of space spread from movements against Middle East dictators to European protests against austerity, neoliberalism and capitalism. The global Occupy movement also appropriated symbolic space as its primary statement of protest against the fabled global economic elite or 1\% (Ramadan, 2013: 146). In 2013 protestors against the private redevelopment of Istanbul's public Gezi Park symbolically inhabited Taksim Square. Their eviction sparked large-scale demonstrations reminiscent of the Tahrir Square protests. Thousands of demonstrators streamed across the Bosphorus bridges into Beyoğlu to protest their dissatisfaction with the increasingly authoritarian policies of the Turkish government. Turkish police responded with an excessive use of force (The Washington Post, 2013).

Similarly, June 2013 saw hundreds of thousands of protesters take to Rio's streets and 80 other Brazilian cities. Sparked initially by an increase in bus fares, the protests grew to 
demonstrate growing disaffection with a range of issues including corruption, increased taxation and spending on the 2014 FIFA World Cup and 2016 Summer Olympics (Watts, 2013).

While these protests often began with specific claims, they spiralled into general calls for variations of Henri Lefebvre's Right to the City - a demand to participate in the production of urban space "in emancipatory ways" (Welty et al., 2013: 153). Tahrir Square's protest camp, argues Ramadan, "was not as an instrument of sovereign power and intensified bio-political control, but a space of freedom, resistance and liberation, a space beyond the control of the state and outside the normal political order, in which a more progressive politics was forged and made real" (2013: 146). The Arab Spring and Occupy movement's intrinsic embeddedness in public space presented a visionary alternative to static socio-economic and political order. While the Arab Spring has achieved its objective in Tunisia, Libya remains contested, Syria in civil war, and Egypt is in a politically unstable and indeterminate state.

As Occupy movements have vacated their specific sites, Schneider states that "the remnants of the movement are dispersed and frustrated, though many are continuing on in struggles against global warming, worker abuse, discriminatory policing and more" (2013). And while global movements peak and fall, protesters and their supporters continue to imagine a different, more equal future. It isn't often that peaks of protest crash over like tsunamis bringing radical change. The power of protest rests in its ability to slowly and steadily dismantle the infrastructure of social, economic, political and environmental inequality. 


\section{The Neoliberal City versus The Public City}

Central to the Occupy movement's challenge to economic and political elites is the notion of the neoliberal city. Global cities tussle for capital and investment, often radically altering their urban form at the cost of the needs of local residents (Desai, 2012; Candan and Kolluoğlu, 2008; McDonald, 2008).

The free market economy emphasises the protection of private property and interprets welfare as the sum of individuals' wealth, far from the natural interdependence and the communal production of goods - what originally brought us together as citizens. This focus on private interest radically removes 'cityness,' or the great collective oeuvre, to use Henri Lefebvre's term, from our urban environments. Cities should ideally be organized around collective interests, within which residents in egalitarian democracies should have equal rights, benefits, and share common values (Swyngedouw, 2011).

As opposed to purely private interests and efficiency, a collective making of the city presupposes potential conflict among individuals who nevertheless share a vision of what public interest is. The project of city making consists of defining and providing a space for the expression of mutual interests in the form of public space (Aureli, 2011). We define the Public City as one that provides and enhances diversity, urban intensity, productivity and democracy to all residents and visitors alike. Central to this notion is a city without socio-economic or political costs, where we as a collective people have, "a right to change ourselves by changing the city" (Harvey, 2008).

Public space is, however, often not profitable. Governments that have surrendered to a market agenda can thus fail to create good cities. Instead, they indiscriminately promote property investment of any kind - even when unproductive in relation to popular 
requirements and needs. White elephant Olympic stadiums in Athens and Beijing, and condominium surpluses in Manhattan, reinforce Brazilians’ 2013 arguments against excessive public spending in the sports events they will be hosting. As David Harvey contends, this frenzied fight to secure global capital signals a wave of city-building sans the civic: "We are experiencing an era where the rights of private property and profit surpass any other kind of rights, where the capitalist economic model leave little steering space for the governments" (ibid).

If facilitating investment and capital accumulation continues to be a central driver of urban decision making, and the needs of financial institutions continue to be placed ahead of the public, a world of privatised, anti-democratic cities will be created. In this way, the financial crisis is a crisis of urbanism.

$<$ FIGURE 3 (large) $>$

\section{PART 2: SITE ANALYSIS}

\section{Physical Boundaries}

'The construction of 'security zones' around the strategic financial cores and government districts of London and New York directly import the techniques used at overseas bases and green zones" (Graham, 2011).

Almost 2000 years ago, what is now the City of London had a Roman city wall that defined its perimeter. Even though the wall has come down, the City still deploys a spectrum of physical, symbolic, and virtual elements to maintain this boundary, including 
the surveillance network termed the 'Ring of Steel' (Fig. 4). We began this research at the Barbican complex, at the northern edge of the City of London, selected due to its existence as a zone of residential, cultural and public exception in the City. After exploring the Barbican's public spaces and their extensions into the City, we began researching the economic, political, social, and physical boundary conditions that influence the character of its public spaces and the City of London as a whole. Richard Sennett (2008) describes boundaries as guarded, static divides, as opposed to borders, which are porous and can facilitate flows of exchange. In the post-WWII reconstruction era, the City rebuilt with the intention of creating a mixed-use and pedestrian-friendly zone. The Barbican is a result of this, and was anticipated to have an active relationship with and be connected to the rest of the City. This modernist vision included pedestrian highwalks (Fig. 5), which aimed to facilitate public life separated from street level traffic (Hebbert, 1993). Although envisioned as an elevated network disseminated throughout the City, the plan was never realised and the pedways for the most part were not built beyond the Barbican boundaries. As a result, the pedways expose pedestrians to bleak, disorienting landscapes that isolate Barbican residents and visitors, rather than inviting new flows of interaction, hybridity, and intensity.

$<$ FIGURE 4 (small)>

$<$ FIGURE 5 (small) $>$

The incomplete pedway system indicates a larger limitation of the City's public spaces. Both at the pedway level and ground level, building facades and lobby spaces that bespeak defensiveness and control communicate to pedestrians the City's role as an efficient business district. Public space is designed for particular uses and users (Fig. 7), resulting in boundaries that stifle flows of exchange between diverse publics. While a de 
facto public realm exists in the City's plazas, parks and pavements, their contribution to a vibrant 'public city' is minimal. As Sassen (2005) unpacks in her talk on 'cityness,' public access does not alone determine how a space performs as 'public'. The lobbies of corporate office blocks and towers form parts of the City's pristine, guarded boundaries. Blank walls of concrete and glass contain interior-oriented worlds that are uninviting to passers-by (Sennett, 2008). Although glass lobbies may be transparent, security guards, surveillance cameras, and immaculate furnishings signal that these spaces function as discriminating thresholds and status symbols, rather than as connected parts of the 'public city'. Examples of these programmatically exclusive yet physically transparent interiors include the OMA's New Court building for the Rothschild headquarters, Royex House at Aldermanbury Square, and the Royal Bank of Scotland at Threadneedle Street. The entrance to the Corporation of the City of London's marketing office also exemplifies a facade of exclusion. Although technically a public amenity offering information to parties interested in leasing office space in the City, its entrance is a locked, mirrored glass door that is monitored by a security camera and its interior display of brochures are available only at the discretion of a security guard. Another example of public space dedicated to the display of power is the courtyard in front of the Guildhall the City's official chambers for political and ceremonial functions since 1440 . The vast stone plaza is bare of public amenities such as seating, planting, or other indicators that invite people to eat their lunch, linger, or do anything but pass by. Another City-wide securitisation of public space is the absence of public trash receptacles. Because they are viewed as a potential depository for explosives, the City of London accepts that people will deposit garbage in the street, circulating street sweepers and cleaning trucks six times a day instead of providing this public service (City of London Police, n.d.). 
inequality and western wealth, and the interests of property owners such as the Bank of England, have combined to produce an almost militarised reaction to the idea of public space. This logic reduces the resident or user to a foreign force and public space becomes a battleground. The adoption of 'military urbanism' is reinforced by neoliberal processes, mainly through the protection of key power groups (and their private interests) and the continued control of urban space, as a means to counter threats (Graham, 2011).

\section{Social Boundaries}

The private thresholds and control systems that permeate the ground level of the City create an atmosphere that prioritises the efficient movement through rather than engagement within public spaces. The spatial influence on social behaviour is evident in how the public presence of the 'floating population' of 300,000 is invisible, with the exception of intense intervals of commuting and consumption. It is also evident in the manner in which two very different cities actually make up the City-the City by night versus City by day. The Square Mile's spatial influence literally deters any sort of night or weekend life from gaining a foothold within its perimeter. Its homogenous demographic profile also shapes the public realm's efficient performance and lack of diversity. $87 \%$ of City workers are white, $80 \%$ work in finance and business services, and $82 \%$ arrive by rail (City of London, 2006). In the film 'Aftermath of a Crisis,' media scholar Gustavo Cardoso points out that while 'bankers' are blamed for causing the economic crisis, there is little social research on who they are, what kind of everyday experiences they have, and what kind of city they want (van der Haak, 2011). Today the finance sector is encapsulated into securitised tower blocks, hidden within complex computing networks (Pardo-Guerra, 2010), and individualised in the space of laptops and smartphones. These social and physical boundaries of the workplace are strengthened by the intensification of 
private security networks that protect financial systems and evade public visibility and access.

$<$ FIGURE 6 (large) $>$

Over the course of four months of site documentation and field interviews, we observed a public culture of efficiency and convenience on the peripheries of office buildings. Workers from both the finance and service sectors take smoking breaks, talk on cell phones, and consume take-out lunches in service alleys, the alcoves formed by scaffolding, and other mundane non-spaces that contrast with the prestigious plazas and lobby spaces of the places where they work. The sheer lack of basic infrastructure such as trashcans and benches deters even the most vital and basic of activities. Instead, the City invests in sophisticated, costly infrastructure and policing mechanisms whose sole purpose is to ensure and maximise the efficiency of business and financial flows. For example, the steady flow of traffic must be ensured at all times. Even the UriLift Public Pop-Up Toilets installed by the City of London near St. Mary-Le-Bow Church do their part; emerging at $10 \mathrm{pm}$ and disappearing at $3 \mathrm{am}$, they efficiently and simultaneously deter public urination by night and ensure that traffic remains unobstructed by day (Monaghan, 2012). Stalled traffic poses a security threat and interrupts the timely delivery of firms' dry cleaning; both jeopardise profits and efficiency. Even within the City of London's 'open' and 'public' spaces, the insufficient amount of basic infrastructure, coupled with a sense of surveillance and the perception that spaces may constitute private property, influences the behaviours that occur, or fail to do so; loitering is infrequent, lunches are short, skateboarding is rare. The stark imbalance between the amount and quality of infrastructure for individuals, versus the infrastructure dedicated to business and profits within the Square Mile, creates a city of 
unequal flows; efficient flows from individuals to the items or things they require to carry out business conveniently (dry cleaning, office supplies, food), and from individuals to the services they provide, but significantly less so between individuals, especially outside of a professional or business context. Our interviews with seventeen current and former City workers on how they use public space in the City confirm this site observation and reinforce our reading of corporate culture as taking place in the private interiority of opaque architecture. Our interviewees who work in finance, marketing and retail described their interactions with the public realm as defined by convenience and efficiency: short lunch breaks that involve purchasing a sandwich, going to an ATM or chemist, and making private phone calls on the street or in the bathroom. This demand for timely everyday amenities results in a highly served urban context. Of the fifteen people with whom we spoke who currently work in the City, only one described using a public amenity for a non-essential, leisure activity. In a conversation in January 2012 interviewee A., a trader in her 30s working at a leading global bank outlined her routine: arriving by rail, grabbing breakfast from the cafe on her trading floor, leaving at lunch time for 10-15 minutes to purchase a take-away lunch, and then buying a tea or snack at 4PM, again from her trading floor cafe - each time, consuming the food at her desk. During her 7:30AM to 6:30PM workday, the only leisure activity A. described was using the office gym two days a week for thirty minutes and occasionally walking home to South Kensington, rather than taking the Tube. On the same date interviewee S., a 31 year-old bond trader who previously worked in the City and is now based in Mayfair, shared his disdain for the homogeneity of the City: “The worst thing to do is to work around people like you: white, finance and boring. The City of London is dull. Canary is worse." In contrast, in Mayfair, he enjoyed the diversity of people he saw on the street, being in proximity to art galleries, and visiting cafes and restaurants during and after work. His colleague, interviewee C., a 36-year-old managing director, also expressed 
preference for working in Mayfair because of the more relaxed pace and varied social mix of the neighbourhood: 'Here it's like you're on holiday. People walk slowly, they're not bankers - they're normal people. If you're surrounded by people who walk fast, you walk faster and this makes you stressed out ... it's not healthy running around like an idiot." While the City's homogeneity and efficiency may not differ greatly from that of other global business districts, it stands out in particular contrast to the City's original trading business run from public coffee shops in the eighteenth century (Kynaston, 1987) and the vital city envisioned in renderings for the twentieth century pedway system.

$<$ FIGURE 7 (small)>

\section{Political and Economic Boundaries}

The City's political system is perhaps its thickest boundary, which remains almost unchanged since 1067 (City of London, 2009). The Corporation of the City of London has adapted this medieval political system into a contemporary governance structure that privileges businesses as citizens - approximately 24,000 business votes outweigh 9,000 resident votes - which results in pro-business policies for the City (Lavanchy, 2009). As journalist Nicholas Shaxson exposes in his investigation of global tax havens, this homogeneous group of political stakeholders poses "little or no risk that democratic politics will intervene and interrupt the business of making (or taking) money" (2011: 10). Corporations are allocated votes in proportion to the size of their workforce and then CEOs select who votes - thus the larger the company, the greater influence they have on the outcome of the political process (City of London, 2009). This quasidemocratic electoral system is exacerbated by the City's Livery Companies, whose members are solely responsible for electing the Sheriffs and Lord Mayor (Figs. 1 and 2). 
The City of London does not fully comply with UK Freedom of Information legislation and is exempt from certain parliamentary regulations, thus evading the country's democratic systems and requisite public participation and accountability (Monbiot, 2011 and Quinn, 2011).

$<$ FIGURE 8 (large) $>$

The City of London generates over $20 \%$ of the country's total financial services. Its large foreign financial network circulates $37 \%$ of global financial share and trades approximately 1.2 trillion pounds at the LSX every day (City of London, n.d.). In light of the recent financial crisis, we have termed it an onshore 'tax island' on welfare - a financial centre reliant on public funds to bail out its UK banking tenants, as it opposes post-crisis UK and EU proposals for new tax structures and regulations (National Audit Office, 2011 and The Economist, 2012). Since 2007, public bailouts pledged to private UK financial institutions have totalled $£ 456$ billion, more than five times the $£ 83$ billion in public sector cuts planned over the next three years (National Audit Office, 2011 and Meadaway, 2011). This corporate reliance on public funds contributes to the City's total financial productivity, yet its exemptions from UK democratic systems and public sector sacrifices make the City an object of contention both locally and within the EU (ibid).

$<$ FIGURE 9 (small) $>$

While London as a whole ranks as a top city for financial productivity, it lags behind other cities in Europe and business cities around the world most dramatically in terms of quality of life and environmental health (Mercer, 2011). In a survey of companies leaving London, 69\% cited poor quality of life as the reason for relocation (Global Financial 
Centres Index, 2011). Beyond base efficiency of worker and capital flows, opportunities for social interaction and information exchange are critical to the collective health and the productivity of a city. In their proposal for urban regeneration strategies in the wake of the 2008 financial crisis, Burkhalter and Castells describe how enriching flows of movement are paramount to urban productivity:

"Functional cities and a functioning economy rely on timely and efficient movement of people, information, and goods... [The] quality and number of connections created by people to people and people to information is an essential factor of productivity. The more quality connections a person can establish in an average day, the bigher the chance of that person adding innovative value to the economy"

(Burkhalter and Castells, 2009: 24).

Our definition of the public city is grounded in a concept of a new kind of efficiency that is not concerned with functionality and ceremony, but instead is fuelled by an intensity and diversity of exchange that culminates in both economic and social productivity.

\section{PART 3: INTERVENTION}

Our vision for the City of London would involve inverting the current governance scheme to balance public good with private interests and radically increase democracy. The public city we envision would create new hybrid typologies of business-residency efficiency and productivity that promote a collective wealth of opportunities and public interactions. High connectivity to public transport and a local electoral system dominated by business interests defines the City's existing efficiency as a top performing business district. Its demographic and political imbalance may yield high productivity for private businesses, but it generates an incomplete and under-performing public realm. We seek 
to define a new efficiency for the City - one that builds on its existing connectivity and amenities while diversifying its stakeholders and maximising its range of uses. Our intervention is rooted in the context of widening economic inequality and unemployment that has intensified in the current financial crisis. It also responds to the City's underperforming housing density as set by the GLA's housing density matrix - currently, the City provides eight times less housing than the target density based on its connectivity (Fig. 10). Our method of addressing this under-performance and enhancing efficiency within the City is to increase its residential population. We propose adding high quality private housing stock that will cultivate an inclusive public realm and promote economic opportunity and social mobility across socio-economic positions. By giving workers the opportunity to live within walking distance of their jobs and residents the chance to build "linking social capital" by living centrally (Putnam, 2000), we would improve the overall quality of life for workers and residents alike. As Richard Florida has argued, "putting people close to their work makes an economy more competitive" (Jacobs and Pickard, 2011). We elaborate on this dictum, adding that integrating a residential population into a work zone will catalyse economic opportunity and social mobility. Our intervention also aims to increase the City's competitiveness as a high-performing business district in comparison to its local rivals, Canary Wharf and Mayfair, as well as to other business cities globally.

$<$ FIGURE 10 (large) >

\section{Policy}

Our research has developed a residential policy and strategy for designing a more public twenty-first century finance City. Both the policy, but especially the imaginative and creative process underpinning this new vision and strategy for the Square Mile, provides 
practitioners and readers alike with a daring and playful way to analyse and understand urban landscapes that challenges normative definitions and expectations of urban 'strategies' for transformation, as well as the transformative process itself. Although we detail a specific vision for the City of London, its broader aim is to familiarise practitioners with a creative savoir faire, a step in the design process, that is applicable to any range of urban projects and landscapes, and that disrupts the all too often cut and dry, bureaucratic, costs-and-margins processes of urban planning and development.

We examined the socio-spatial possibilities of the City of London through an exploratory lens that included crafting guidelines for implementing a residential strategy, as well as a body of work that explores how such guidelines can stretch, transform, and increase the socio-spatial fabric of the City. The vision resulting from this process reverses the City's exemption from contributing affordable housing within its territory (City of London, n.d.), and offers the City of London a platform to address its home building obligations within the Square Mile, rather than continuing to export affordable homes to neighbouring boroughs (Fig. 10). Although the City is a leading location for the financial services sector, firms are increasingly concerned about a loss of talent and face competition attracting and retaining employees courted by firms in other financial centres such as New York, Hong Kong, Shanghai, and Seoul (Lloyd's, 2011 and Global Financial Centres Index, 2011). Through our residential strategy, we propose a revitalisation of the Square Mile and its under-performing public realm by introducing a new residential population within its political boundaries. Composed primarily of employees in the City, this new population will transform the Square Mile into a more public city by multiplying its socio-spatial functions. This increased diversity of spaces and programme will enable firms to better attract and retain talented employees by filling the gap between productivity and quality of life. 
We propose introducing 52,000 new residents by 2025 into the City of London (Fig. 11). This would dramatically restructure the political process, as well as political participation. The new population would increase the City's residential population to 60,000 , inverting its current political and power balance. Residents would have $73 \%$ of City votes and businesses $27 \%$ (Fig. 11). In addition, and in keeping with the traditions of the City, we recommend the formation of a new livery company, The Worshipful Company of Residential Occupiers, to which all City residents would be invited as members. This livery would grant residents a place in local decision making bodies and influence the appointment of the Lord Mayor (Fig. 12).

$<$ FIGURE 11 (small)>

$<$ FIGURE 12 (small)>

Our spatial strategy outlined (Fig. 11) incorporates residential units to accommodate a diverse socio-economic breakdown of residents and to maximise the City's high realestate value and its underutilized public spaces. We propose the introduction of 24,000 residential units from 2014 - 2025. Focusing on compact residential units that vary in finishes and amenities, and correspondingly by price, makes populating the City with tenants who are focused on increasing their professional development, at varying professional and socio-economic levels, conceivable (Fig. 11). Top earners will be drawn to the possibility of maximising their efficiency by living close to work, while a range of tenants, at varying socio-economic levels, will be drawn to the networking, social, and economic opportunities that come from living in the City. Unlike the exclusive lifestyle facilitated by developments such as the Heron, the compact residential units we envision house people of diverse socioeconomic backgrounds in close proximity to each other 
and are strategically clustered within nodes of business activity and connectivity to transport (Figs. 13 and 16).

$<$ FIGURE 13 (small) >

Categorising the socio-economic profiles of potential tenants will ensure a diverse resident population plays a central role in our vision for the City of London. Details such as a funding scheme outlining pricing and lease guidelines, subsidies making a certain quantity of units affordable for minimum wage workers, salary requirements with qualifying minimum and maximum earnings, and tenure policies are all crucial for establishing mechanisms by which resident turnover ensures a dynamic population of diverse socioeconomic backgrounds and multiplies the opportunities for living in the City.

Efficiency is central to our vision for the City of London, and actually we propose that significantly populating it with a diverse population increases opportunities for interaction, exchange, and intensity that boost individual, business, and collective efficiency and productivity. Herein lies the key to understanding why the City of London Corporation would be interested in becoming an active stakeholder in implementing such a vision and undertake responsibilities such as retaining sole ownership of all rental units and administering them; leasing office space, roof space, etc., when applicable, in which the residential units and programming shall be added; removing residential units from any building if/when space becomes required by a business, upon review of lease; and relocating units within the Square Mile to ensure the total resident population does not decrease. Such specifications are meant to promote the City's productivity by designating only one party with whom businesses and residents 
will interface, as well as the fluidity necessary to ensure that a residential strategy implemented within the City of London increases its overall efficiency and performance as a leading international financial and business centre. The fluidity of our residential strategy, the manner in which residential units and programme can be plugged in, removed, and plugged in again elsewhere, describes a dense urban landscape that we envision becoming highly adaptive, experimental, responsive, capable of ensuring the needs of residents and businesses alike are met, and thus highly efficient.

In order to realistically accommodate the needs of our proposed resident population, public space with the City must not only increase, it must also be similarly characterised. Making gyms, roof gardens, terraces, canteens and boardrooms of businesses throughout the City accessible to the new resident population, according to a reasonable and equitable usage agreement between the City of London Corporation and the concerned parties, so as not to disrupt collective efficiency and productivity, can transform the Square Mile's heavily policed and uninviting public areas into active, open spaces conducive to intense interaction and exchange (Fig. 18). Digital resources can be leveraged to streamline resident access to the increased type and quantity of public space we envision taking root in the City of London. For their part, businesses that make amenities publicly accessible can benefit from this public exposure as part of their corporate social responsibility and branding efforts, as well as yield new income.

\section{Physical Analysis and Intervention}

The City of London was historically home to over 100,000 residents up until the mid1800s (Kynaston, 1987). Although a dense residential population may seem inconceivable in today's City, we believe the City's spatial DNA has proven to be incredibly resilient and elastic. In many parts, the City preserves its medieval street 
pattern, while accommodating the block and tower morphology of the contemporary city. Another example is the doubling of the City's office stock that occurred between 1985 and 1993, in response to the digitisation of the market and the need to build floor plates to house trading floors and an increased number of workers (Burdett, 1994).

We have identified three urban morphologies that are prevalent throughout the City's built fabric: medieval, block and tower. By evaluating these three morphologies, their opportunities and constraints, we offer an approach to installing residential units across the City. In order to achieve a residential population of 60,000 by 2025 , we envision the incremental addition of 24,000 apartments through strategic phasing. In mapping connectivity, social infrastructure and amenities we identified three central nodes where the installation of residential units could begin. These are located around Bank, Liverpool Street, and Thames Citylink Stations. These nodes host functions key to resident needs and they have significant block morphology office stock. The insertion of apartments would begin within close proximity of these intensity nodes and then extend across the City (Fig. 14), disrupting the current segregation of residents into particular wards. In our initial intervention phase, we estimate accommodating 520 residential units at these three nodes in the first year, then gradually increasing annual output to reach 7,800 in 2025 . We propose beginning the installation of residential units within the block morphology because its rationalised structure would lend itself to this kind of spatial intervention. Gradually, residential units would be introduced into the medieval and tower morphologies, which necessitate greater sensitivity to spatial forms. We recognise that intervention in each of the morphologies must consider issues of entry, circulation, lighting, ventilation and security on a case-by-case basis.

$<$ FIGURE 14 (large) > 
Our strategy for the City of London entails intervening in and working with three different urban morphologies. In doing so, we aim to increase overall efficiency, as discussed in the previous section, but building on these forms is in and of itself efficient because it maximises existing infrastructure, connections, and flows. Although all three morphologies have at some point contributed to the current stasis and lack of diverse productivity within the City, pockets or instances of productive flows and exchange do occur within each. Engaging and maximising these productive pockets is central to our vision and strategy for each of the Square Mile's urban morphologies; clearly, it would be counter-productive and inefficient to disrupt established infrastructure and flows of efficiency. Identifying nodes of connectivity, social infrastructure, and amenities is a first and critical step in the process of maximising the efficiency and productivity already afoot in the City of London. It is especially important to engage in this process within the City's medieval morphology, which has proven particularly resilient across time and change, as well as conducive to flows and exchanges of all types, including those designated by street names such as Milk Street, Bread Street, and Threadneedle Street.

\section{Block}

The block morphology makes up about $58 \%$ of the City of London's built fabric. The large floor plates of buildings within this morphology, such as Capital House on King William Street and the BT Centre on Newgate Street, offer key opportunities for converting underutilised space into residential units and amenities. The large, open roofs and blank facades within the block morphology could accommodate the installation of residential units and significantly increase the City's residential stock. We envision residential units in the spacious, open-floor plans of large buildings within the block morphology. For example, instead of leaving entire floors of big office buildings vacant 
for long periods, they can be temporarily converted into high quality studio apartments (Fig. 14). Such conversions within the block morphology would likely prove less complicated and more cost effective than in the medieval or tower morphologies, due to the streamlined and standard layout of many of its office buildings. Many such buildings actually often temporarily transform floor plans by putting up and taking down nonessential walls and partitions to accommodate the changing sizes and needs of businesses and individuals to whom they lease office space. The manner in which businesses alter their workspace by arranging and rearranging cubicles is another example of the kinds of spatial transformations already taking place within office buildings of this type. These conversions, as well as projects such as Spacebox by Netherlands based De Vijf (Spacebox, 2011), and the prefabricated, lightweight steel pods providing much needed homes for vital key workers in London Borough of Hammersmith and Fulham (Blunden, 2011), illustrate how residential units can be inserted into underutilized and convertible spaces within the block morphology.

The temporality of such an intervention would allow the converted residential space to be reconverted back into office space as the need arises. It is for these reasons that we have identified the block morphology as the best morphology for initial insertion; it offers the ability to host the largest number of residential units with the least amount of disruption. Although the installation of residential units within an office building would require a rearrangement of programmes and management, new revenue streams would be generated from otherwise vacant office floors. From 2009 to 2011, office vacancy in the City averaged at 9.3\% (The City of London, 2010 and Capita Symonds, 2012). We consider the installation of homes within already existing, vacant office infrastructure a means of creating a 24-7 environment for areas of the City that become desolate during evenings and weekends (Fig. 15). 
$<$ FIGURE 15 (large) >

\section{Tower}

Skyscrapers have been a controversial addition to the City's skyline since Britannic House (now City Point) was constructed in 1967 as the first building taller than St. Paul's Cathedral in the City (Simon, 1996: 3). The modernist high rise and its elevated forecourt, which connects to the City's elevated pedway network (Best, 1968: 23), imagined a city of uniformity and order, where the labyrinthine alleys left untouched by WW2 bombs are seen as dark, congested and potentially unsanitary.

The construction of skyscrapers in the City has continued in Bishopsgate mainly with a small cluster forming near the Barbican. Building booms occurred mainly in the 1970s and 2000s. Today a number of new tall buildings have recently been constructed or are currently being built. Their curious nicknames such as The Gherkin (30 St. Mary's Axe), Cheese Grater (122 Leadenhall Street) and Walkie-Talkie (20 Fenchurch Street) have emerged in the public discourse and are based purely on their formal resemblance to common objects.

At $13 \%$, the tower morphology makes up the smallest percentage of the City of London's built fabric. This morphology has the greatest potential for high-density residential intervention. Not only do we envision office space within the towers being converted into residential units and amenities, but built interventions on top of and between towers will make the most of underutilised and available space (Fig. 14). Because towers have small footprints, as well as high quality, robust infrastructure 
already in place, we believe they offer viable opportunities for accommodating high density and quality apartments. Our exploration of possible interventions within the City's tower morphology was informed by MVRDV's the Cloud, a planned mixed-use residential complex in Seoul (MVRDV, 2011). The Cloud consists of two high rises connected by units that maximise the space between the towers. We imagine many opportunities for residential interventions that append, bridge, and plug into the City's tower morphology without impeding their office functions.

The public's ambiguous enchantment with the City's changing landscape lends credence to the radical reconceptualisation of a block of towers as vertical infrastructure ripe for infill (Fig. 16). In the same spirit as Modernist planners and architects who stitched together buildings with sanitised pedways, new connective architectural membranes and extensions could create vital space for new dense housing stock. A cocktail stick could impale the Gherkin, off which a spider's web would trap the Cheese Grater and an enormous USB drive could rewire the Walkie-Talkie.

$<$ FIGURE 16 (large) $>$

\section{Medieval}

The dense, labyrinthine, medieval morphology of the Square Mile makes up about 30\% of its built fabric (Fig. 17). A good example of this morphology is the inner-temple or the area of offices directly west of the Barbican. The insertion of residential units within the medieval morphology would be incremental and respect its distinct character, which in some instances is the result of centuries of urban accretion. The medieval morphology's architecturally diverse fabric and human scale allows for intimate public spaces. Out of the three morphologies, we would integrate the fewest number of residential units here 
because its current form already largely maximises available space and connectivity. Due to the delicate and varied nature of the medieval morphology, we envision primarily installing or plugging residential units into it and utilising the infrastructure and amenities of the nearby block and tower morphologies for public space opportunities. The Nomiya Restaurant, placed on the roof of the Palais de Tokyo, hints at the possibility of sensitive interventions in the City's medieval morphology, utilising prefabricated components attached to existing building infrastructure (Studio Laurent Grosso, 2009). The resilient medieval pattern of the City with its sequence of spaces is considered today to facilitate public 'cityness'. The winding street with its small-scale street side shops, offices and residences is ideal for encounter and exchange. We want to exploit the medieval street pattern as the base for diversifying and intensifying social relations. Higher density and 'congestion' will activate urban life.

$<$ FIGURE 17 (large)>

\section{Public Space}

In addition to residential policy, our vision for public space in the City of London is critical. In order to accommodate a residential population of 60,000 , the quality of public space within the City must be improved.

The hyperdensities tested by our research underscore the need for a reconceptualisation of public space, for "such multifaceted infrastructure [public open space, schools and other critical infrastructures] forms the prerequisites for making hyperdensity not just livable but enjoyable" (Chakrabarti, 2013). Importantly, Chakrabarti goes on to underscore the open-ended nature of experiments into the best formal qualities or language of the hyperdense morphology (2013). Critiqued as 'transitory' and 'ephemeral' 
by Douglas Kelbaugh (2001: 14.7), this 'experiment' in the public spaces of a new, hyperdense City of London presents a transformation of the physicality and experience of the public realm.

Without truly reconsidering these civic arenas beyond their defined spatial boundaries and dimensions, society risks stagnating in the physical while rapidly advancing in the digital. This is not a fruitless argument for advancement at all costs, nor does it conflate democracy with disorder (as opposed to oppressiveness with order) (Kelbaugh, 2001: 14.2) but instead calls for an entangled urbanism that seeks to achieve a more democratic and equal city through productive adjacencies and encounters.

"Truly great architecture invites, uplifts and advances its city. A great building invites the public through physical or phenomenological transparency; it shows itself to the city even while veiling surprises within. A great building inspires people through its beauty and material qualities, while enhancing the coherence and contradictions of the street" (Chakrabarti, 2013).

Modern day protest camps have come to define radical imaginations of the public sphere. Traditional and often highly symbolic public spaces are radically changed and reinvented, albeit temporarily, by the public they belong to. As seen in the Occupy movement, makeshift residences adjoined tents fulfilling library and 'university' functions offer a glimpse of the multiple opportunities of flexible public space. Defining the protest camp as "a public space of transformative political action and radical progressive change" (Ramadan, 2013: 148), allows, at a much greater scale, the conceptualisation of a city defined by its radical and progressive public spaces. Far from singular in function and dimension, these spaces can occupy multiple planes and surfaces in the digital as much as the physical, blurring thresholds and provoking new synergies. 
More accessible public spaces that facilitate a diverse range of interactions amongst a diverse range of users are necessary in the City. Opportunities for public space should be increased, and existing spaces improved by transforming the already existing infrastructure and amenities of City businesses into public or semi-public spaces. Steps to radically reduce a dependence on cars in European cities such as Hamburg present a future public where up to $40 \%$ of the city will be covered by a pedestrian-oriented green network (Paterson, 2014). Here, however our 'green network' is a public realm that combines the pedestrian- and leisure-oriented nature of green networks with a public space strategy planned to root more residents in a healthy and connected, yet hybrid, heterotopian and sensational public space morphology.

The roof gardens, canteens, gyms, boardrooms, lobbies, cafés, courtyards of businesses and firms within the Square Mile are of a high calibre, but are restricted in access. As our proposed intervention is imagined to unfold and residential units are installed in converted office floors, plugged into the facades of buildings and built on to available roof space, residents' public space needs can be met by gaining access to these business amenities. These underutilised spaces within the City, such as certain roof spaces, lobby spaces and vacant office spaces, can be converted for public use by residents and workers alike (Fig. 18). To avoid replicating a gated community effect, in which residents and employees have access to high quality amenities that remain inaccessible to the wider public, we will make a number of business amenities accessible to the public. In order to facilitate general accessibility to certain appropriated and converted public spaces, such as boardrooms, without compromising business needs, online booking networks can be used to query and reserve these spaces. Our vision for public space within the City builds on the design precedents in other global financial centres. For example, Dwell 95 by 
Yoo, a Wall Street office tower converted into rental flats, has been programmed with amenities, such as free weekday breakfast, a roof-top terrace, a gym and business centre, promote interaction and efficiency (Starck, 2008). Our vision for the public city goes further by reconceptualising the City's private amenities as a public good.

$<$ FIGURE 18 (large)>

\section{CONCLUSION}

The City of London's public realm is defined by static boundaries of historic governance systems and exclusive corporate tenants. To transform the City's boundaries into productive borders, we propose integrating a kinetic residential typology within the existing infrastructure. We see the global financial crisis as an impetus for the City of London, and other business-purposed urban districts, to consider using design as a method of productively responding and reconnecting to the its surrounding urban fabric. We imagine opportunities to create hybrid, multi-scalar and multi-programmed public spaces, complemented by an equally responsive and dynamic residential intervention (Fig. 19). We expect our focus on reshaping the City's residential form to have potent political implications. While speculative, this project corresponds to a new political push for more residents being accommodated in the City. National policies that would facilitate the City's conversion into a mixed-use neighbourhood are already under consideration. In light of the UK housing crisis, David Cameron ordered a review of the national planning system in the summer of 2011, including a proposal to allow developers to convert offices in the City of London into residences (Jacobs and Pickard, 2011). Under the government's vision, there would be a reversal of the long-term population decline and low residential density of the Square Mile, creating thousands of flats in the midst of the business landscape. UK planning minister Greg Clark favours 
this increase in the City's residential population and does not accept the City's practice of exporting its housing to other boroughs:

"Having people living in city centres is a fantastic thing. It civilises cities, so they are not ghost towns at night. . . I know the Corporation of London takes a view that the City is different to most places. But we are very clear that it is important and desirable to have greater flexibility" (ibid).

Developers are also eager to convert offices into flats because residences are currently worth up to double the value of offices (City of London, 2010). One of the main triggers of the 2008 financial crisis was the collapse of subprime mortgage markets due to predatory lending and trading practices (Burkhalter and Castells, 2009: 24). There has also been acknowledgement that the Occupy movement has managed to influence policy makers through cultivating a global attitude that extreme inequality is unacceptable and that has, in turn, shaped elements of financial reform in the UK (Inman, 2012). Our research proposal offers a positive reconnection between the everyday domestic realm and the financial sector that has fuelled its foreclosure. We imagine a particular city of compact residences and diverse residents that are integrated into hyper-connected public space. We offer dynamic spatial strategies for a twenty-first century finance city, in which local governing bodies and corporations can adapt design as a method to create an inclusive public city. Quite often, spatial, social, economic, and political strategies for transformation pit productivity and profits against quality of life; we are forced to choose either or, particularly in times of economic crisis and austerity. However, in the City for which we advocate, this dichotomy is false, and productivity and quality of life are not mutually exclusive. We describe an urban landscape in which current efficiency and productivity are not only conserved, but one in which a drastically improved quality of life and expanded public realm become the means by which efficiency and productivity 
are boosted and maximised. The strategy we outline to repopulate the City of London and achieve these aims challenges normative residential strategies for urban transformation, as well as assumptions about how space must be appropriated and utilised in order for them to be implemented. Because residential strategies generally deal with the brick-and-mortar of real estate and residential units and the 50+ year lifetimes of buildings, strategies for implementation are couched in a language and vision of permanence and rigidity. We counter such normative assumptions by offering a residential strategy for urban transformation that is characterised by temporality, flexibility, and fluidity. While the establishment of a new residential population of 60,000 within the Square Mile shall remain permanent, the manner in which space is appropriated and utilised to achieve this will not; office space converted into residential units during year one of implementation can be converted back into office space in year four and reconfigured as public space in year ten. In this manner, the City we envision is constantly reinventing and reconfiguring itself, maximising efficiency, and participating in the flows of creativity, exchange, and productivity that characterise it as a leading global business and financial centre. It is doing what the City has always done best with the transformative power of difference and equality.

$<$ FIGURE 19 (large) > 


\section{REFERENCES (Including all image references)}

Aureli, P. V. (2011) The possibility of an absolute architecture, Cambridge, MA: MIT press.

Best, A. (1968) 'Britannic House gets special treatment' in Design Journal, 236,

http://vads.ahds.ac.uk/diad/article.php?title=236\&year=1968\&article=d.236.15

[Accessed 6 February 2014]

Blight, G; Pulham, S and Torpey, P. (2012) 'Arab spring: An interactive timeline of Middle East protests' in The Guardian, 5 January, http://www.theguardian.com/world/interactive/2011/mar/22/middle-east-protestinteractive-timeline [Accesed 6 February 2014]

Blunden, M. (2011) 'Pod flats to help beat shortage in housing for capital's key workers' in London Evening Standard, http://www.standard.co.uk/news/pod-flats-to-help-beatshortage-in-housing-for-capitals-key-workers-6434676.html [Accessed 9 February 2014]

Bolton, M; Froese, S; and Jeffrey, A. (2013) 'This Space is Occupied!: The Politics of Occupy Wall Street's Expeditionary Architecture and De-gentrifying Urbanism' in Welty, E; Bolton, M; Nayak, M and Malone, C. (eds) Occupying Political Science: The Occupy Wall Street Movement from New York to the World, New York: Palgrave Macmillan

Burkhalter, L. and Castells, M. (2009) Beyond the Crisis: Towards a New Urban Paradigm, http://newurbanquestion.ifou. org/proceedings/1\%20The $\% 20 \mathrm{New} \% 20$ Urban\%20Question/Castells BEYOND\%20 THE\%20CRISIS.pdf [Accessed 22 February 2012] Amsterdam/Delft: The 4th International Conference of the International Forum on Urbanism

Burdett, R. ed. (1994) City Changes: Architecture in the City of London 1985-1995, London: The Architecture Foundation

Candan, A. and Kolluoğlu, B. (2008) 'Emerging spaces of neoliberalism: A gated town and a public housing project in Istanbul' in New Perspectives on Turkey, 39, 5-46

Capita Symonds. (2012) City Development Pipeline, http://www3.nbrealestate.co.uk centrallondon/citymore.aspx [Accessed 12 March 2012]

Centre for Cities. (n.d.) http://www.centreforcities.org/ [Accessed 20 January 2012] 
Centre for Economics and Business Research. (2011) London to lose 27000 City jobs in 2011, http://www.cebr.com/ [Accessed 12 March 2012]

Chakrabarti, V. (2013) 'Building Hyperdensity and Civic Delight' in Design Observor, 13 June, http://places.designobserver.com/feature/a-country-of-cities-buildinghyperdensity/37899/ [Accessed 7 February]

City of London. (2010) City Office Evidence Paper, http://www.cityoflondon.gov.uk/Corporation/LGNL_Services/Transport_and_streets /Street_care_and_cleaning/Roads-street_cleaning_programme.htm [Accessed 12 March 2012]

City of London. (2009) History of the Government of the City of London, http://www.

cityoflondon.gov.uk/Corporation/LGNL_ Services/Leisure_and_culture/Local_history_and_heritageBuildings_within_the_City/ Mansion_house/History+of + the + Government + of + the + City + of + London.htm [Accessed 12 March 2012]

City of London. (2006) Workforce info Census 2001, http://217.154.30.195NRrdonlyres/3181A629-BB40-43F1-926D-

126C8F52889B/0DP_PL_EmploymentWorkforceInfo.pdf [Accessed 11 March 2012] London: Department of Planning and Transportation

City of London. (2005) City of London Resident Population: Census 2001, http:///www. cityoflondon.gov.uk [Accessed 11 March 2012] London: Department of Planning and Transportation

City of London. (n.d.) How the City of London Works, http://www.cityoflondon.gov.uk/Corporation/LGNL_Services/Council_and_ democracy/Councillors_democracy_and_elections/Corporation_organisations.htm [Accessed 11 March 2012]

City of London Police. (n.d.) Roads - street cleaning programme, http://www.cityoflondon.gov.uk/Corporation/LGNL_Services/Transport_ and_streets/Street_care_and_cleaning/Roads-street_cleaning_programme.htm 
[Accessed 12 March 2012]

Davies, C. (2012) 'Occupy London- City wins high court eviction bid' in The Guardian, http://www.guardian.co.uk/uk/blog/2012/jan/18/ occupy-london-london [Accessed 12 March 2012]

Desai, R. (2012) 'Governing the Urban Poor: Riverfront Development, Slum Resettlement and the Politics of Inclusion in Ahmedabad' in Economic \& Political Weekly, 14 January, 67(2)

D\&G Asset Management. (2011) Prime Central London Residential Property: Report May 2011, http://www.primelondoncapitalfund.co.uk/ assets/files/ [Accessed 11 March 2012]

The Economist. (2012) Save the City, 7th January, http://www.economist.com/ node/21542417 [Accessed 12 March 2012]

Ellin, N. (2006) Integral Urbanism, New York: Routledge

Foster + Partners. (n.d.) 30 St. Mary's Axe, http://www.fosterandpartners.com [Accessed 1 December 2011]

Global Financial Centres Index. (2011) The Z/Yen Group, http://www.zyen.com/GFCI/GFCI\%209. pdf [Accessed 12 March 2012]

Graham, S. (2011) Cities under siege: The new military urbanism, London: Verso Books

Great Britain. Greater London Authority. (2011) The London Plan 2011, http://www.london.gov.uk/sites/default/files/The\%20London\%20 Plan\%202011.pdf [Accessed 12 March 2012] London: Greater London Authority

Greater London Authority. (n.d.) London Datastore, Historic Census Population, http://data.london.gov.uk/datastore/package/historic- census-population [Accessed 12 March 2012]

Grim, P. (2013) Two Years Later, What Happened to Occupy Wall Street? Institute for Public Accuracy, http://www.accuracy.org/release/two-years-later-what-happened-to-occupywall-street/ [Accessed 5 February 2014]

The Guardian and The London School of Economics. (2011) Reading the Riots: Investigating England's summer of disorder, 14 December, http://www.guardian.co.uk/uk/interactive/2011/dec/14/reading-the-riots- 
investigating-england-s-summer-of-disorder- full-report [Accessed 12 March 2012]

Gupta, A. (2012) What happened to the Occupy movement, Aljazeera,

http://www.aljazeera.com/indepth/opinion/2012/05/2012521151225452634.html [Accessed 8 February 2014]

Harvey, D. (2008) 'The right to the City' in New Left Review, 53, 23-40.

Hebbert, M. (1993) 'The City of London Walkway Experiment' in Journal of the American Planning Association, 59, 4, 433-450. http:// www.tandfonline.com.gate2.library.lse.ac.uk/ doi/pdf/10.1080/01944369308975898 [Accessed 12 March 2012]

Hetzel, J. ed. (1846) 'Le Diable a Paris' in Paris et les Parisiens, Paris

Inman, P. (2012) 'Bank of England official: Occupy Movement right about global recession' in The Guardian, 29 October, http://www.theguardian.com/world/2012/oct/29/bank-ofengland-occupy-movement [Accessed 5 February 2014]

Jackobs, E. and Pickard, J. (2011) 'Living in London: Vexed in the city' in Financial Times, 26 August, http://www.ft.com/intl/cms/ s/0/88023178-ce7f-11e0-b755-00144feabdc0. html\#axzz1oqun8u5v [Accessed 11 March 2012]

Kelbaugh, D. (2001) 'Three Urbanisms and the Public Realm' in 3rd International Space Syntax Symposium Atlanta Proceedings, 14.1-14.8

Kynaston, D. (1987) 'A Changing Workscape: The City of London since the 1840s' in The London Journal, 2, 99-105

Lavanchy, R. (2009) 'Labour runs in City of London poll against 'get-rich' bankers' in Tribune Magazine, 13 February, http://archive.tribunemagazine.co.uk/article/13th- february2009/6/labour-runs-in-city-of-london- poll-against-get [Accessed 11 March 2012]

Lloyd's (2011) Risk. Index,

http://www.lloyds.com/ /media/Files/News\%20and\%20Insight/360\%20Risk\%20Ins ight/Lloyds_Risk_Index_2011.pdf [Accessed 11 March 2012]

McDonald, D. (2008) World City Syndrome: Neoliberalism and Inequality in Cape Town, New York: Routledge

Meadaway, J. (2011) 'EU deal: Permanent austerity, permanent stagnation' in New Economics 
Foundation, 14 December, http://neweconomics.org.blog/2011/12/14/ [Accessed 12 March 2012]

Mercer. (2011) Quality of Living worldwide city rankings,29 November, http://www.

mercer.com/press-releases/quality-of-living-report-2011 [Accessed 11 March 2012]

Monaghan, A. (2012) 'Crisis, what crisis? The Square Mile fights back' in The Telegraph, 30

December, http://www.telegraph.co.uk/finance/newsbysector/constructionandproperty/9771640 /Crisis-what-crisis-The-Square-Mile-fights-back.html [Accessed 10 February 2014]3

Monbiot, G. (2011) 'The medieval, unaccountable Corporation of London is ripe for protest' in The Guardian, 31 October, http:// www.guardian.co.uk/commentisfree/2011/ oct/31/ corporation-london-city- medieval?INTCMP=SRCH [Accessed 11 March 2012] MVRDV. (2011) The Cloud, http://www.mvrdv. nl/\#/projects/thecloud [Accessed 12 March 2012]

National Audit Office. (2011) The Comptroller and Auditor General's Report on Accounts to the House of Commons, http://www.nao.org.uk/ publications/1012/hmt_accounts_2010-2011.aspx [Accessed 12 March 2012] London: HM Treasury

New Policy Institute and Trust for London. (2011) London's poverty profile, http://www.londonspovertyprofile.org.uk/downloads/ summary2011-v7-LRpages.pdf [Accessed 11 March 2012]

Occupy LSX. (2011) http:/ / occupylsx.org/ [Accessed 10 March 2012]

Occupy Together. (2011) http://www.occupytogether.org/faq/ [Accessed 10 March 2012]

Office for National Statistics. (n.d.) Neighbourbood Statistics 2001 online database, http://www.ons.gov.uk/ons/index.html [Accessed 12 March 2012]

Pardo-Guerra, J.P. (2010) 'Creating flows of interpersonal bits: the automation of the London Stock Exchange, c. 1990-1995' in Economy and Society 39, 84-109

Paterson, T. (2014) 'Auto ban: How Hamburg is taking cars off the road' in The Independent, 15 January, http://www.independent.co.uk/news/world/europe/auto-ban-how-hamburgis-taking-cars-off-the-road-9062461.html [Accessed 7 February] 
Putnam, R. (2000) Bowling Alone: The Collapse and Revival of American Community, New York: Simon $\&$ Schuster.

Quinn, B. (2011) 'Corporation of London: an ancient institution that favours big business' in The Guardian, 31 October, http://archive. guardian.co.uk/Default/Skins/DigitalArchive/Cli entasp?Skin=DigitalArchive\&enter $=$ true $\& A W=1331495420617 \&$ AppName $=2$

[Accessed 12 March 2012]

Ramadan, A. (2013) 'From Tahrir to the world: The camp as a political public space' in European Urban and Regional Studies, 20(1), 145-149

Sassen, S. (2005) 'Cityness in the urban age' in Urban Age, Bulletin 2 (Autumn), http://urbanage.net/0_downloads/archive/Saskia_Sassen_2005-Cityness_In_The_Urban_AgeBulletin2.pdf [Accessed 11 March 2012]

Schneider, N. (2013) Two Years Later, What Happened to Occupy Wall Street? Institute for Public Accuracy, http://www.accuracy.org/release/two-years-later-what-happened-to-occupywall-street/ [Accessed 5 February 2014]

Sennet, R. (2008) The Public Realm, http://www.richardsennett.com/site/SENN/Templates/General2.aspx?pageid=16 [Accessed 9 December 2011]

Shaxson, N. (2011) Treasure Islands, New York: Palgrave Macmillan

Simon, R. (1996) 'Skyscrapers and the new London skyline: 1954-1991' in Architronic, 5(2), http://corbu2.caed.kent.edu/architronic/v5n2/v5n2.06a.html [Accessed 6 February 2014]

Spacebox. (2011) http://www.spacebox.nl/index.cfm?lng=en [Accessed 9 February 2014]

Starck, P. (2008) Yoo: Dwell 95, http://www.yoo. com/pip25_Dwell-95 [Accessed 12 March 2012]

Studio Laurent Grosso. (2009) Nomiya Restaurant, http:// ww.nomiya.org/ [Accessed 12 March 2012]

Swyngedouw, E. (2011), 'The Zero-Ground of Politics: Musing on the Post-Political City' in T. Kaminer, M. Robles-Duran \& H. Sohn (eds) Urban Asymmetries. Studies and Projects on 
Neoliberal Urbanization, Rotterdam: 010 Publishers

van der Haak, B. (2011) Aftermath of a crisis, VPRO Backlight. 5 October, http://www.

youtube.com/watch?v=RjJaheN_S20 [Accessed 11 December 2012]

Vocal. (2011) The aftermath of the UK riots, 15 August, http://vocal.co.uk/news/the-aftermath- ofthe-uk-riots/ [Accessed 10 March 2012]

The Washington Post. (2013) ‘Prime Minister Erdogan's strongman tactics in Turkey’ in The W ashington Post, 4 June, http://www.washingtonpost.com/opinions/prime-ministererdogans-strongman-response-to-turkeys-protests/2013/06/03/6d83987a-cc78-11e28f6b-67f40e176f03_story.html [Accessed 6 February 2014]

Watts, J. (2013) 'Brazil erupts in protest: more than a million on the streets' in The Guardian, 21 June, http://www.theguardian.com/world/2013/jun/21/brazil-police-crowds-rioprotest [Accessed 5 February 2014]

Welty, E; Bolton, M; Nayak, M and Malone, C. (2013) Occupying Political Science: The Occupy Wall Street Movement from New York to the World, New York: Palgrave Macmillan

Williams, H. (n.d.) Ring of steel: Entering the Panopticon, http://henriwilliams.blogspt.com [Accessed 8 December 2011] 


\section{AUTHORS}

Ilana Adleson is a Policy Program Officer at the French-American Foundation, New York, which works to enrich the transatlantic relationship between France and the United States by addressing pressing policy issues faced by both countries. Email: iadleson@ffrenchamerican.org

Sharifa Alshalfan is an architect at AGi Architects, Kuwait, and a research fellow at LSE IDEAS, London School of Economics. Email: salshalfan@gmail.com

Nicolas Palominos is an architect and researcher in Santiago de Chile. He is advisor of Housing and Urban Planning at the General Comptroller Office of the Republic of Chile, and co-director of CAMINABLE, a consultancy that focuses on urban mobility. Email: nicolas@,caminable.com

Guy Trangoš is an architect and researcher at the Gauteng City-Region Observatory, which is a partnership of the University of Johannesburg, the University of the Witwatersrand, Gauteng Provincial Government, and organised local government. Email: guy.trangos@gcro.ac.za

Adriana Valdez Young is an urban researcher based in New York City. She is a programme officer at Community Systems Foundation, a non-profit technology firm that provides information design services to UN agencies and governments. Email: younga@gmail.com 
REORDERED PUBLICS: Re-imagining the City of London

\section{FIGURES}

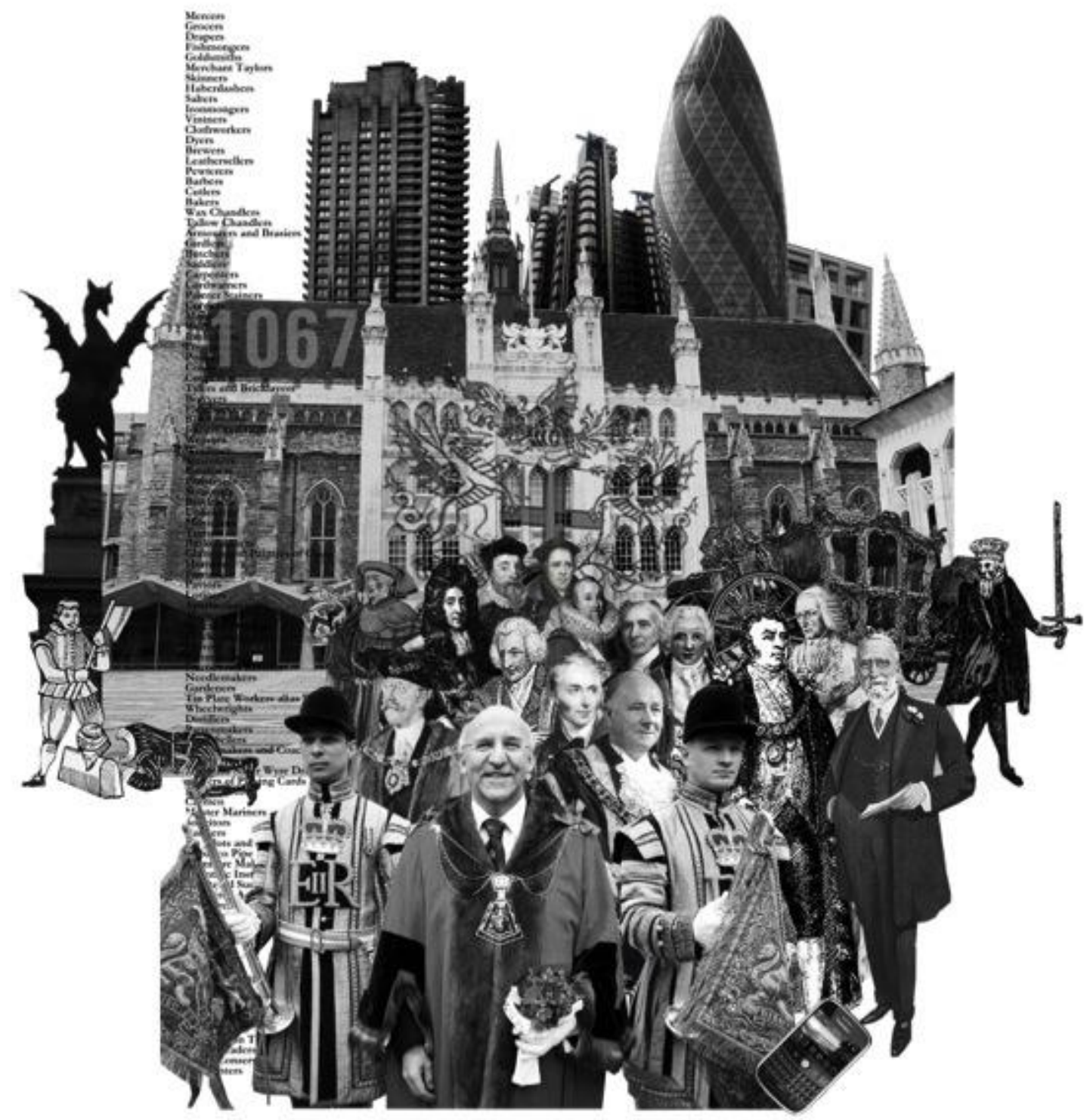

Figure 1: Square Mile Medieval Plutocracy 


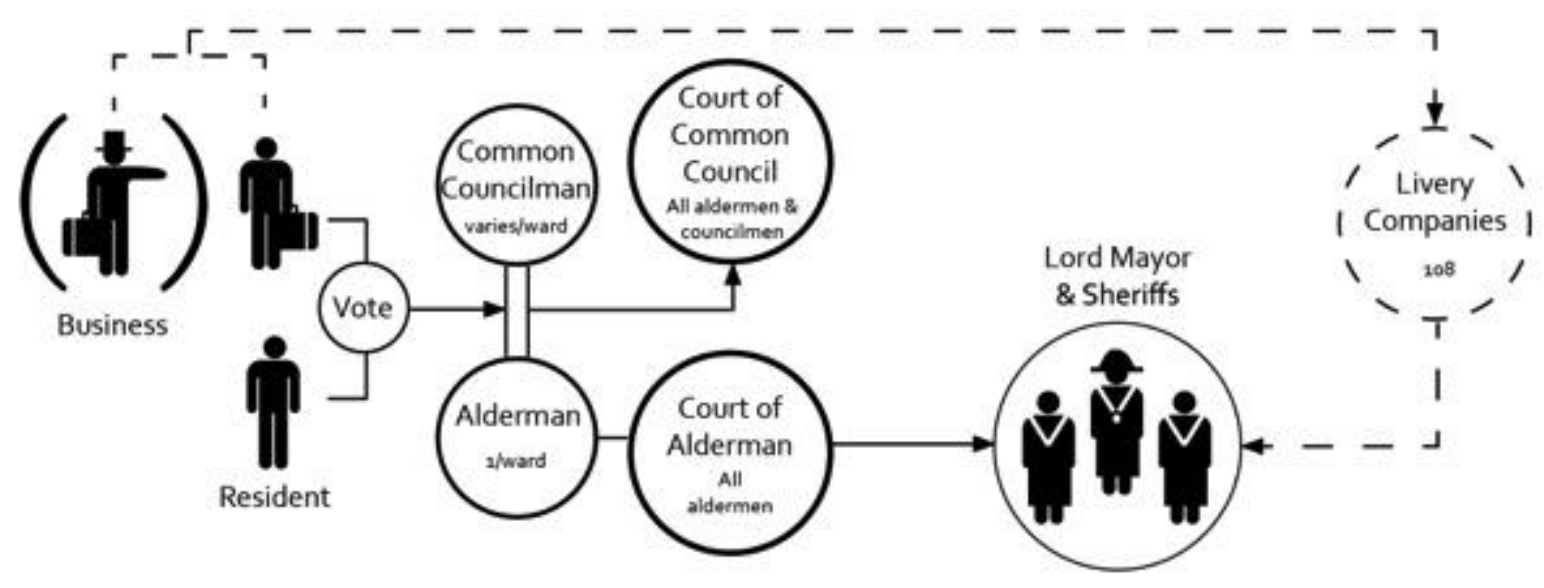

Figure 2: The City voting structure as it currently exists. Business votes currently outnumber residential votes by $75 \%$. Proportional voting based on employee numbers means that business management chooses which staff vote for them. Only members of livery companies, of which $50 \%$ still do not accept female membership can, be eligible for and, vote in the Lord Mayor and Sheriffs of the City. Source: City of London, 2009

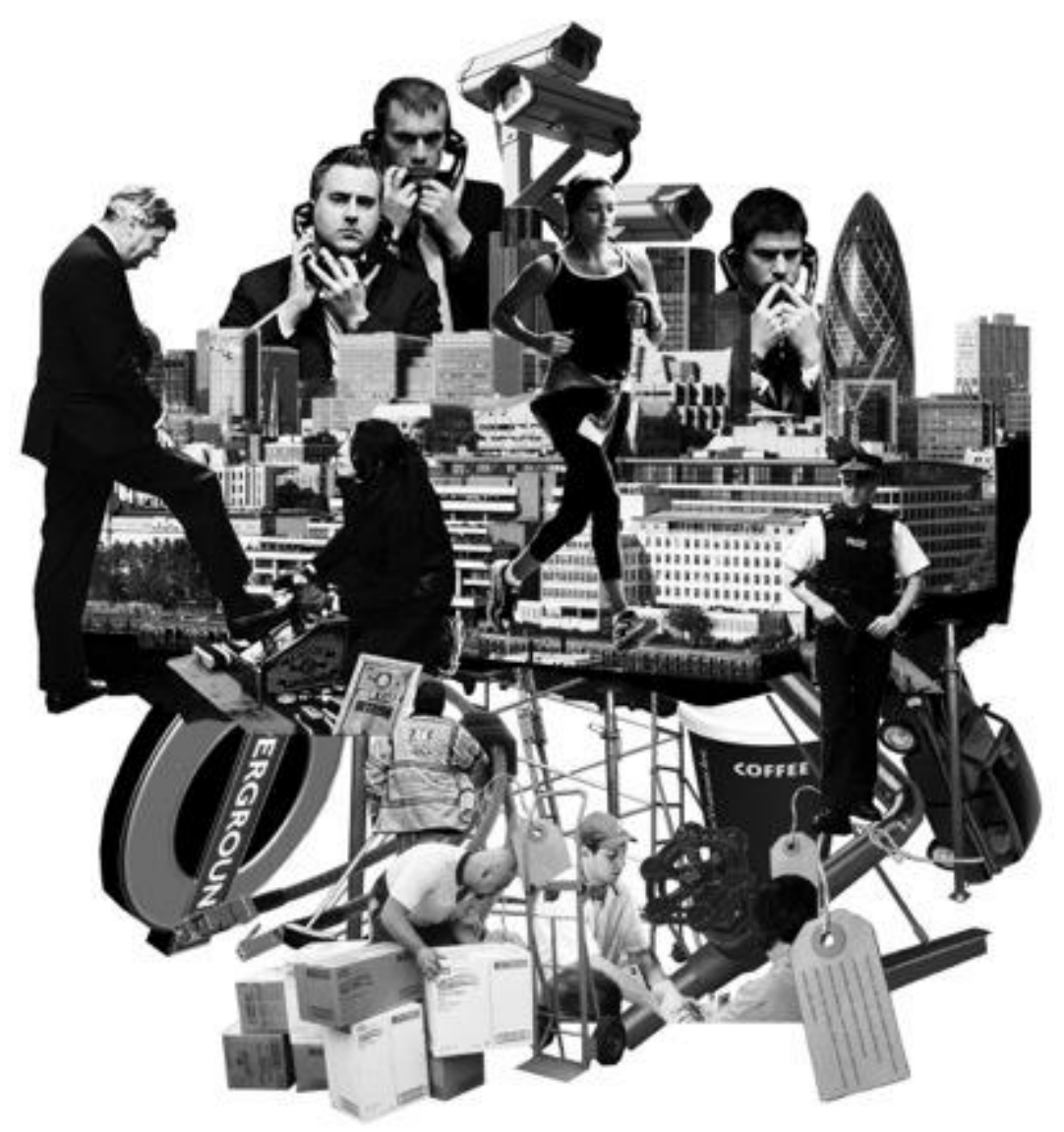

Figure 3: The efficient City: service networks that support and protect business flows 


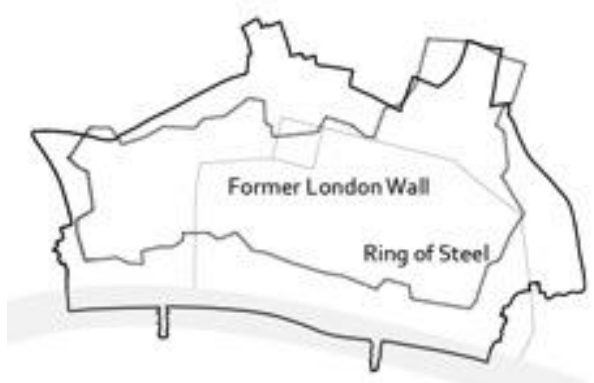

Figure 4: Historical layering of the City's fortifications and its current political boundary. Source: Williams, n.d.
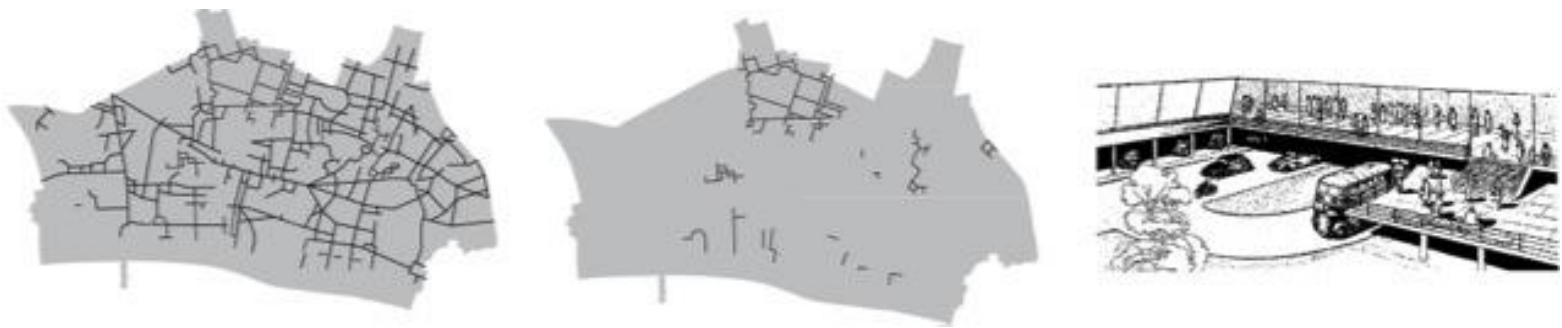

Figure 5: From left: Planned 30mile pedway network 1963; Pedway network built by 1992; Raised public level as imagined in 1941. Source: Hebbert, 1993 


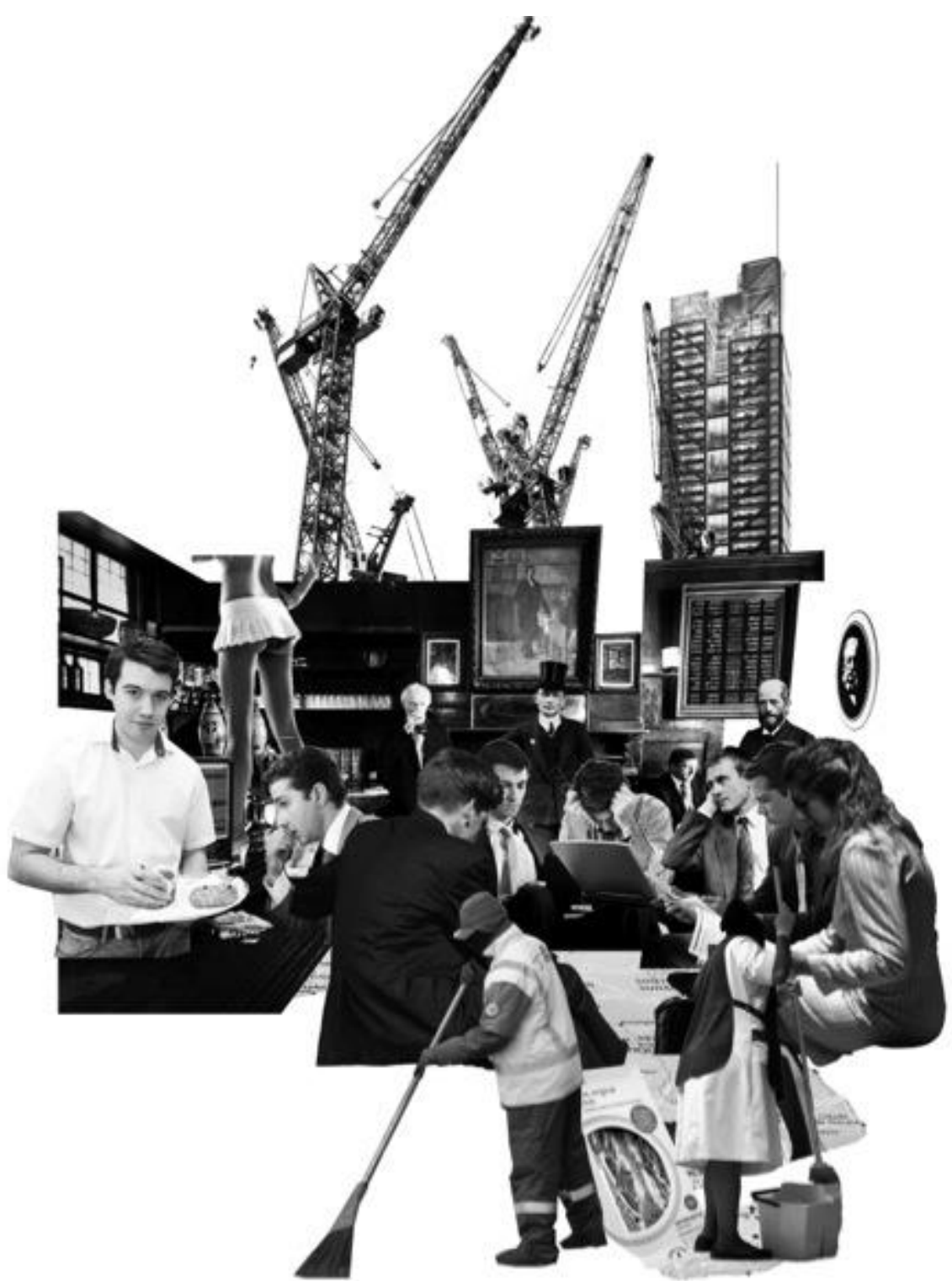

Figure 6: City Worker culture, illustrating work environments from 18th century coffee houses to contemporary coffee chains 

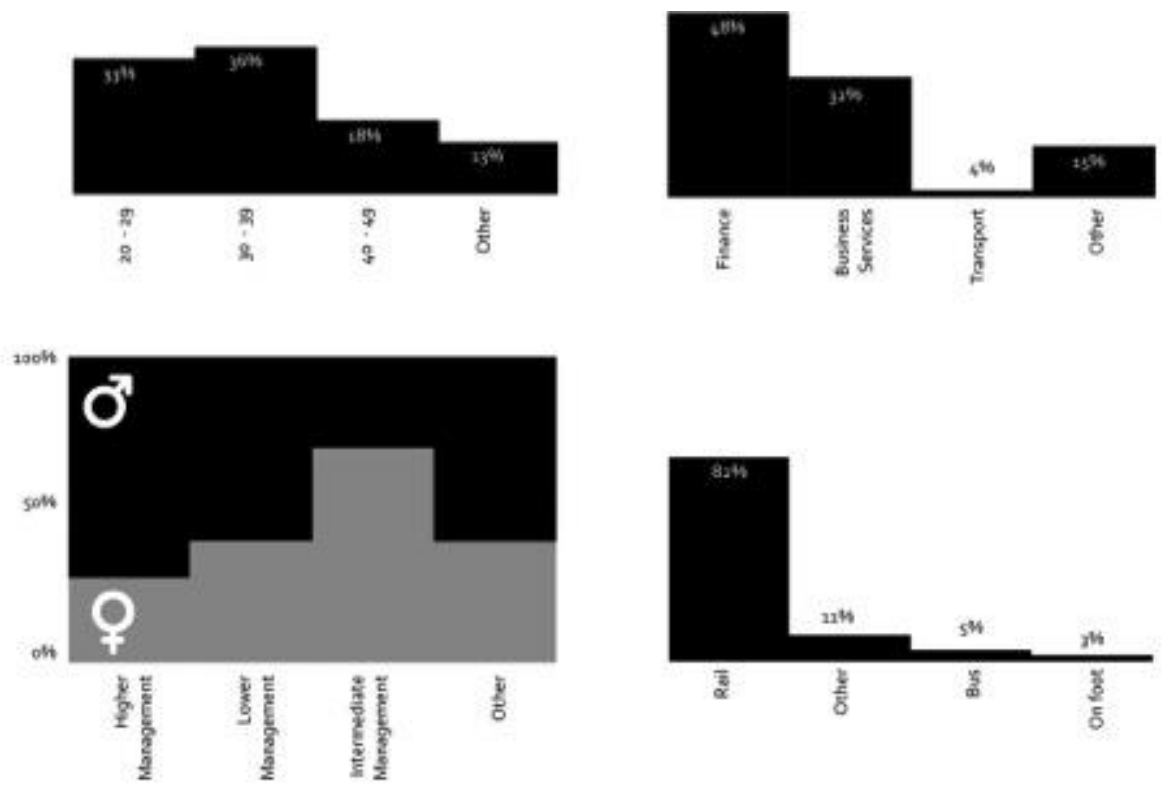

Figure 7: Top left: City worker age profiles. Bottom left: City worker gender distribution according to occupation. Top right: City worker distribution in industrial sectors. Bottom right: Modes of travel to work in the City. Source: City of London, 2006 


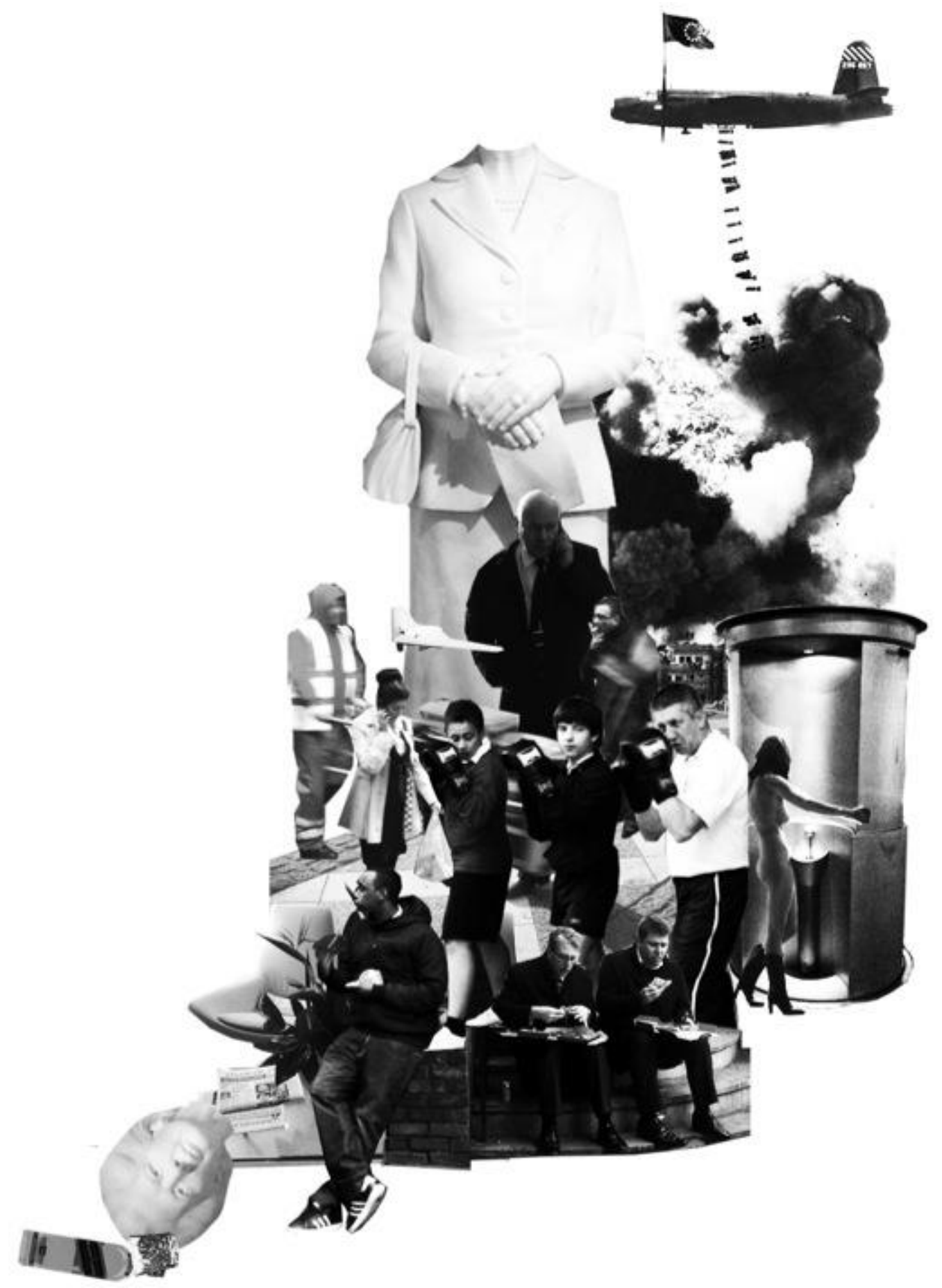

Figure 8: Threats to prosperity: from challenges to neoliberal governance systems and proposed EU regulation to public space used as bare efficiency 

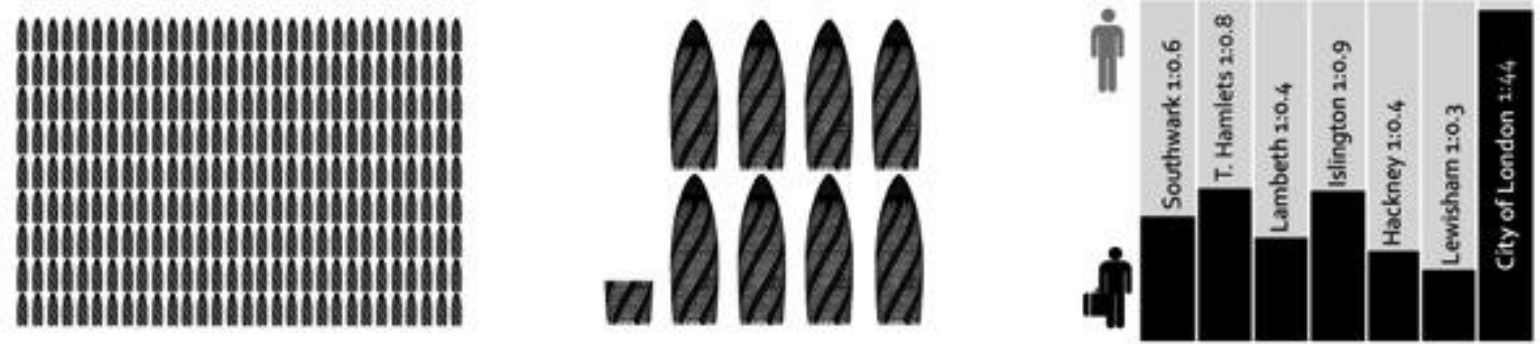

Figure 9: From left: Greater London's 365000 unemployed in 2009 could fill 270 'Gherkins'; The 27000 lost jobs in 2011 in the City would have emptied 8.3 'Gherkins' of office space: Source: New Policy Institute and Trust for London, 2011 and CEBR, 2011 and Foster + Partners; Resident to Worker Ratios in selected London boroughs: Source: Office for National Statistics 

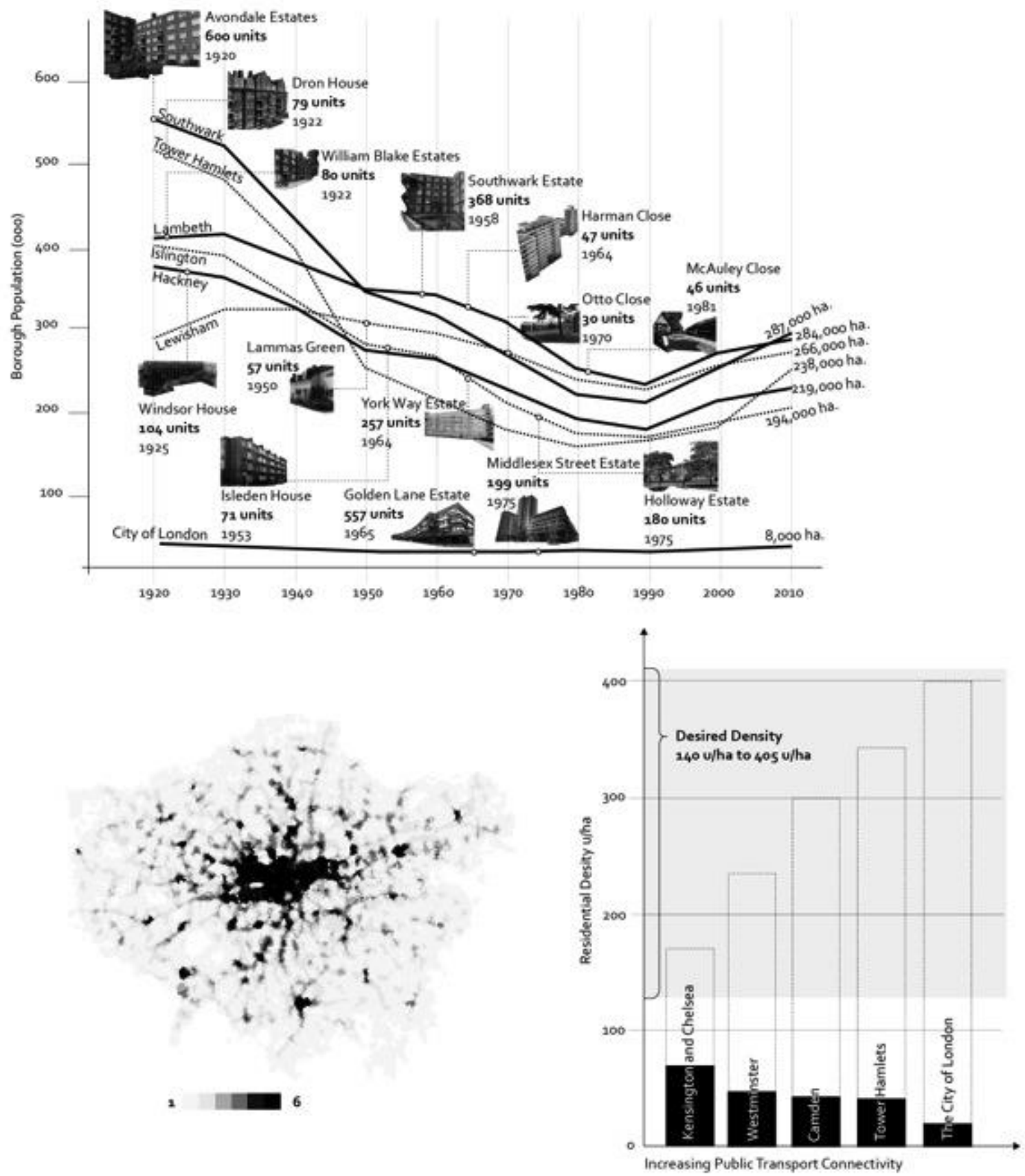

Figure 10: Above: Social Housing schemes built by the City in different London boroughs: Source: City of London, 2005 and Centre for Cities. Bottom left: Public transport accessibility levels across London: 6 being the highest and 1 the lowest: Source: GLA. Bottom right: Disparity of residential density, given public transport connectivity: Source: The London Plan, 2011 and Office for National Statistics 

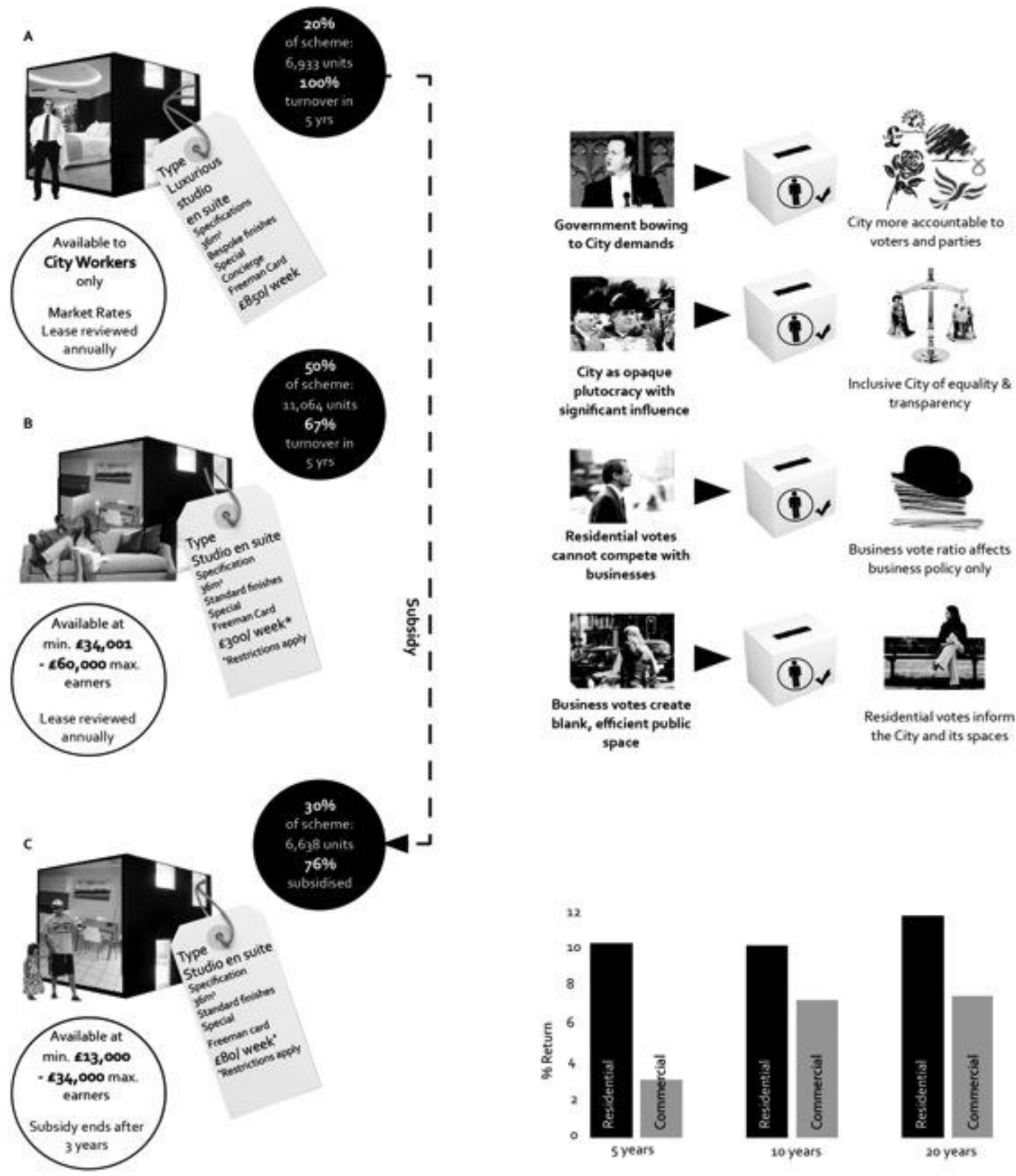

Figure 11: Left: City Living unit specifications and financing. Top right: The impact of a residential vote on the City. Bottom right: Average annual total returns of prime residential property in Central London vs. Commercial to 2009: Source: DeG Asset Management, 2011. 


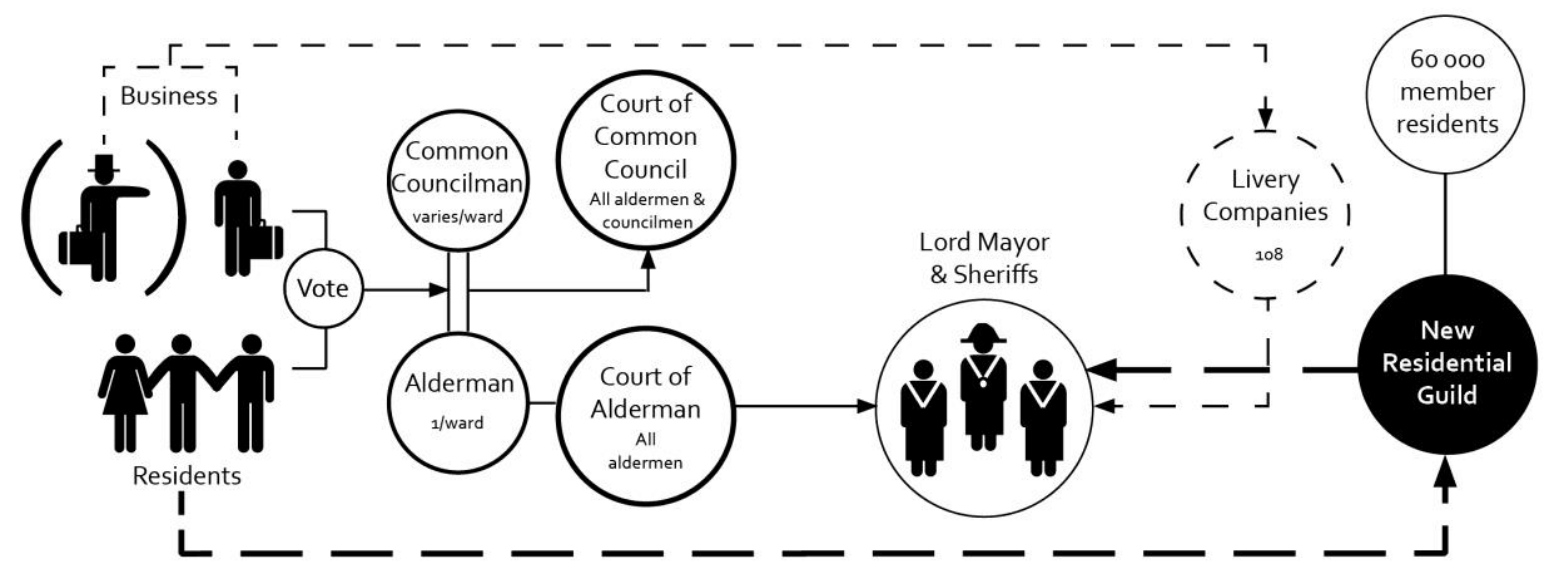

Figure 12: The impact of the establishment of the Worshipful Company of Residential Occupiers. Residents will now be able to have a voice in the election of the Lord Mayor and the Sheriffs, as only livery company members can vote for the City's primary representatives and figureheads.

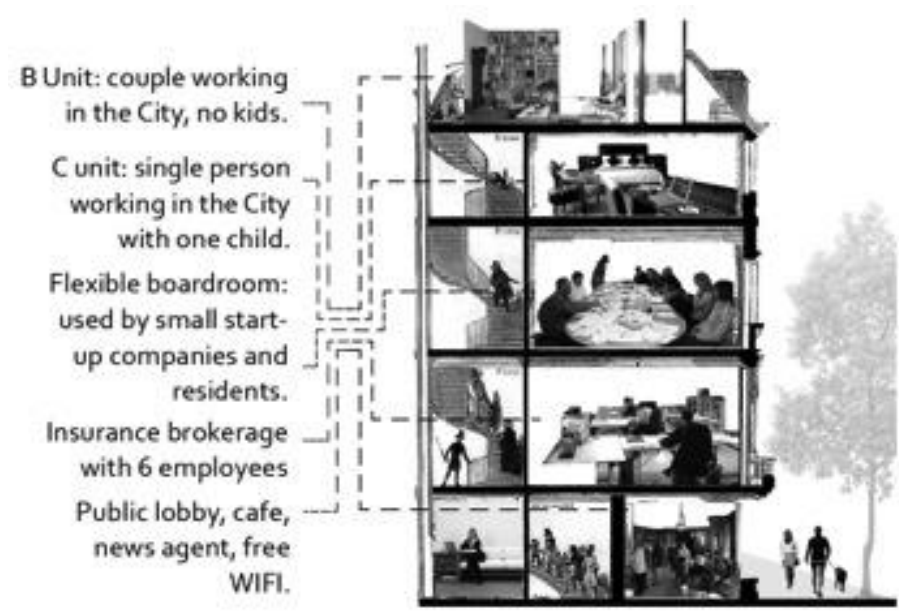

Figure 13: Opportunities for social interaction through mixed functions. Source: Hetzel, 1846 

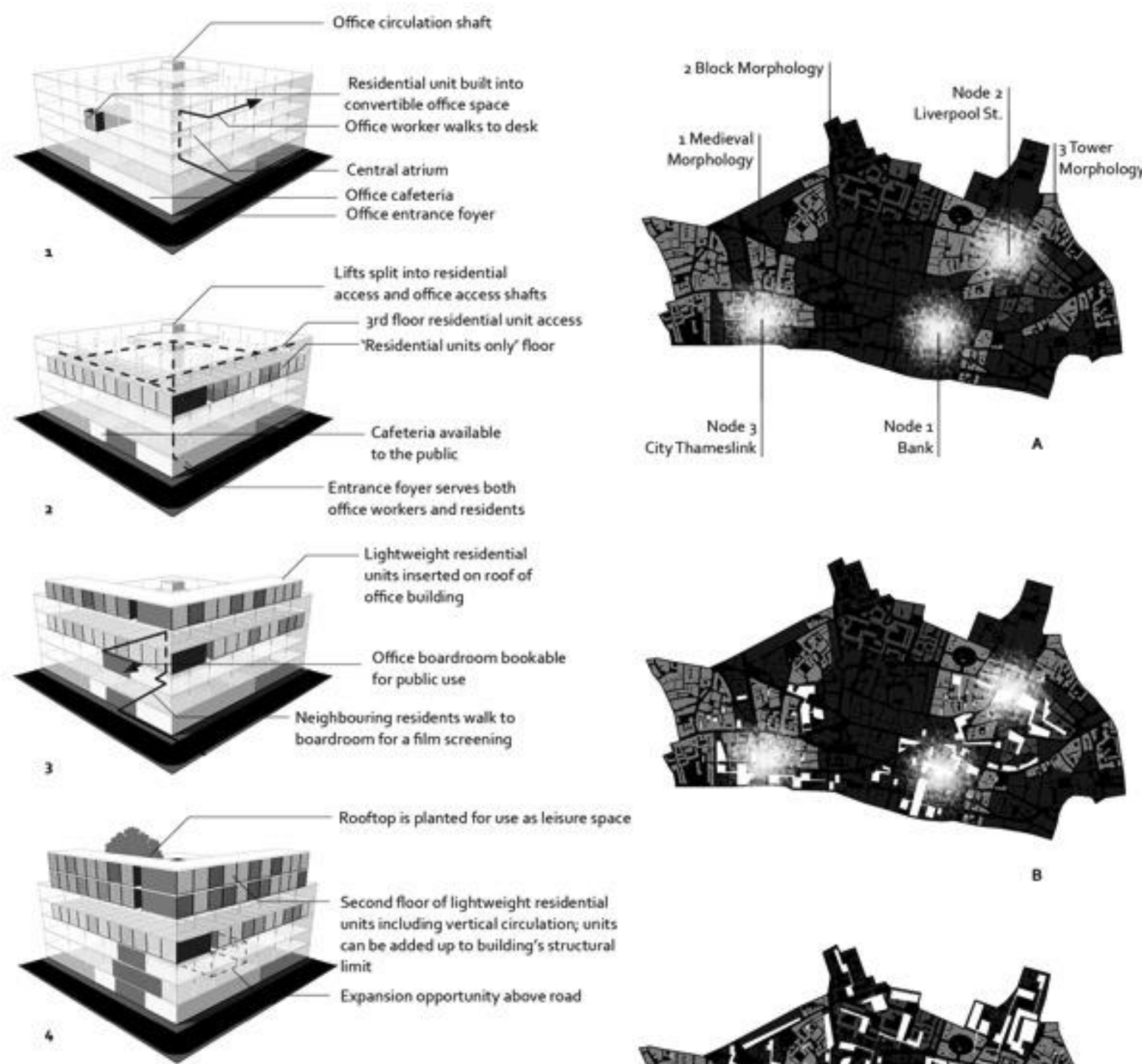

of lightweight residential units including vertical circulation: units can be added up to building's structural limit

Expansion opportunity above road
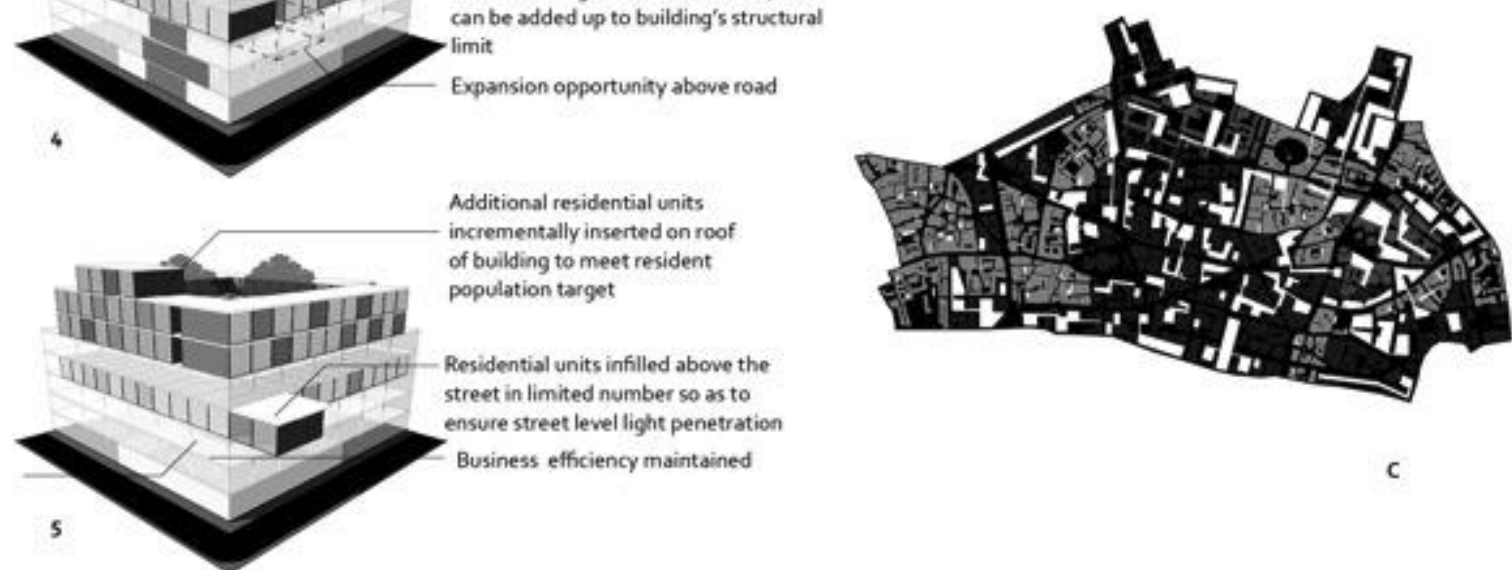

Additional residential units incrementally inserted on roof of building to meet resident population target

Residential units infilled above the street in limited number so as to ensure street level light penetration Business efficiency maintained

Figure 14: Left: The phased insertion of residential units into one generic City block. Right: A - Layering of intervention nodes and morphologies; B - Incremental installation of residential units starting at the overlap of nodes and the block morphology; C - City-wide growth and accretion of residential units 


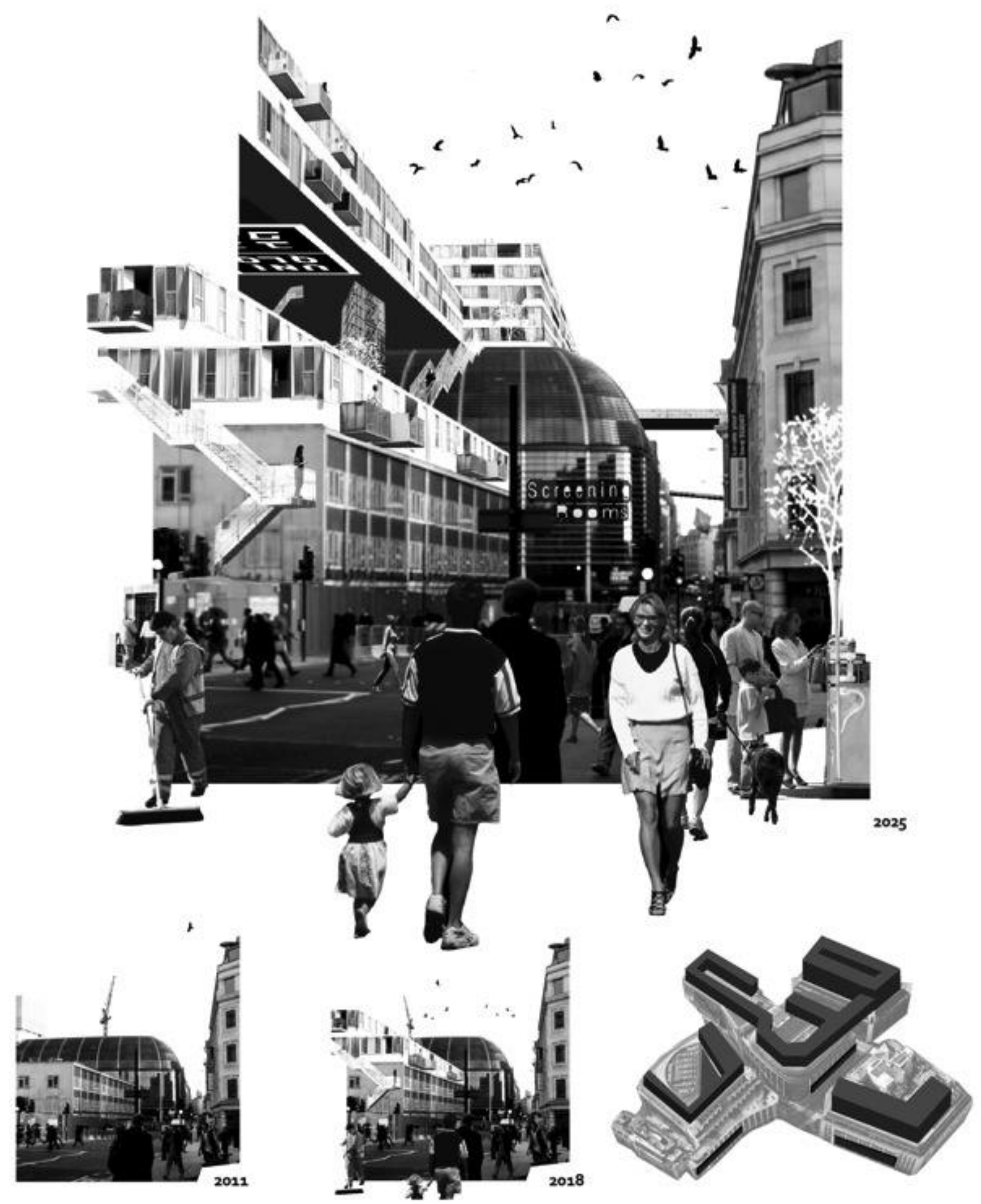

Figure 15: Above: The Block morphology residential intervention, and its effect on the changing public city, as imagined through time. Below: Accretion of residential units on office infrastructure as imagined by 2025 

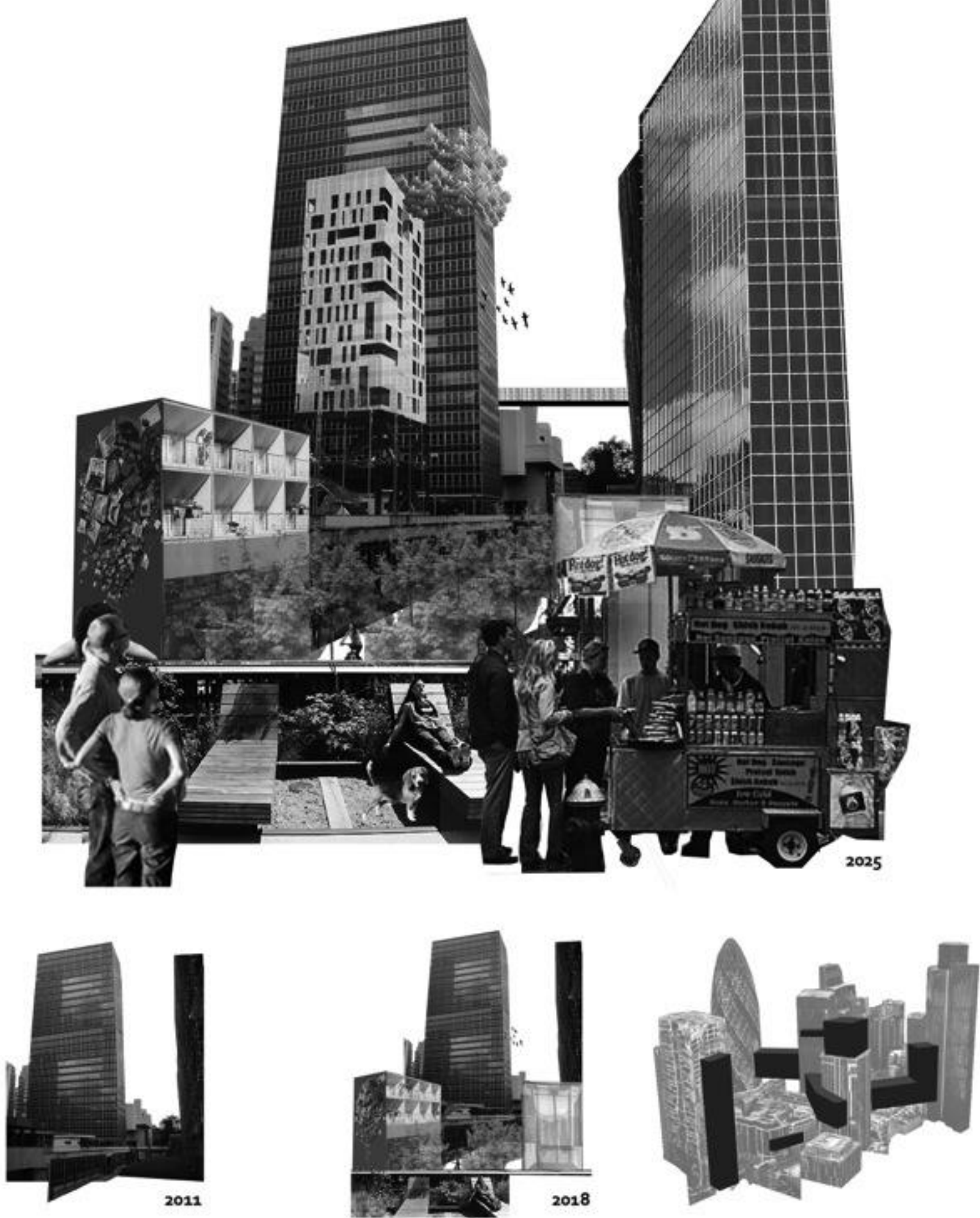

Figure 16: Above: The Tower morphology residential intervention, and its effect on the changing public city, as imagined through time. Below: Accretion of residential units on office infrastructure as imagined by 2025 

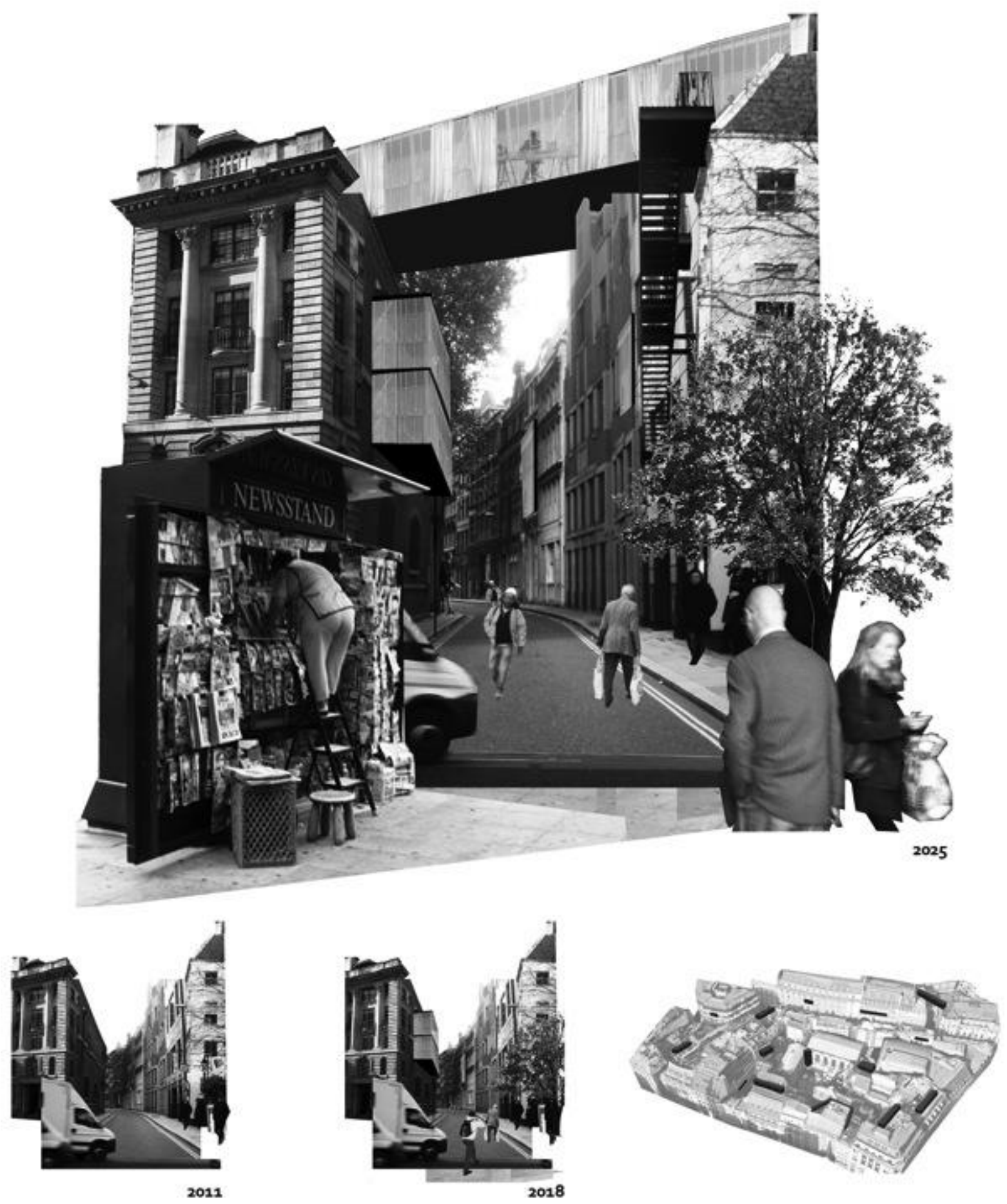

Figure 17: Above: The Medieval morphology residential intervention, and its effect on the changing public city, as imagined through time. Below: Accretion of residential units on existing infrastructure as imagined by 2025 


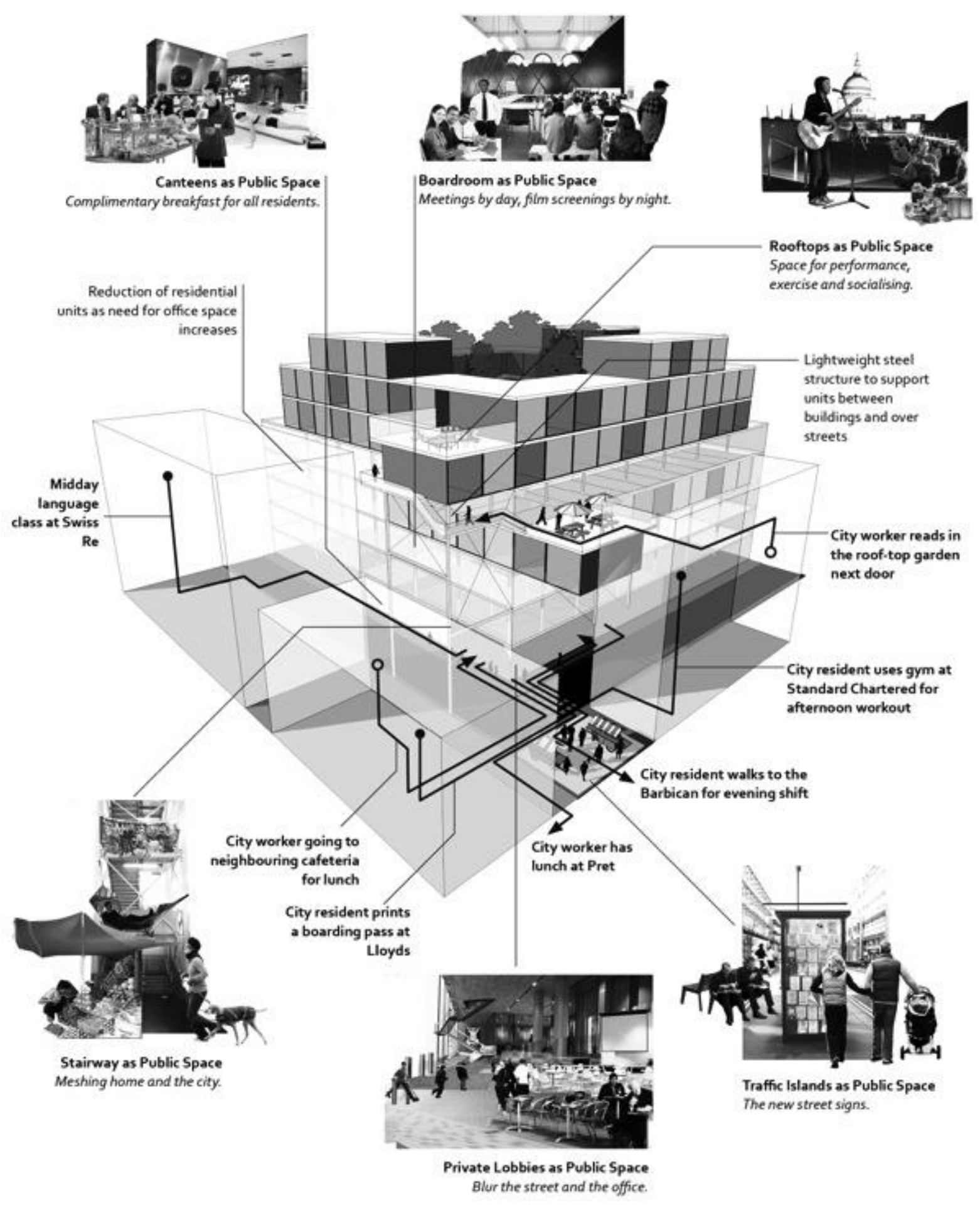

Figure 18: The final phased insertion of residential units into one generic City block 


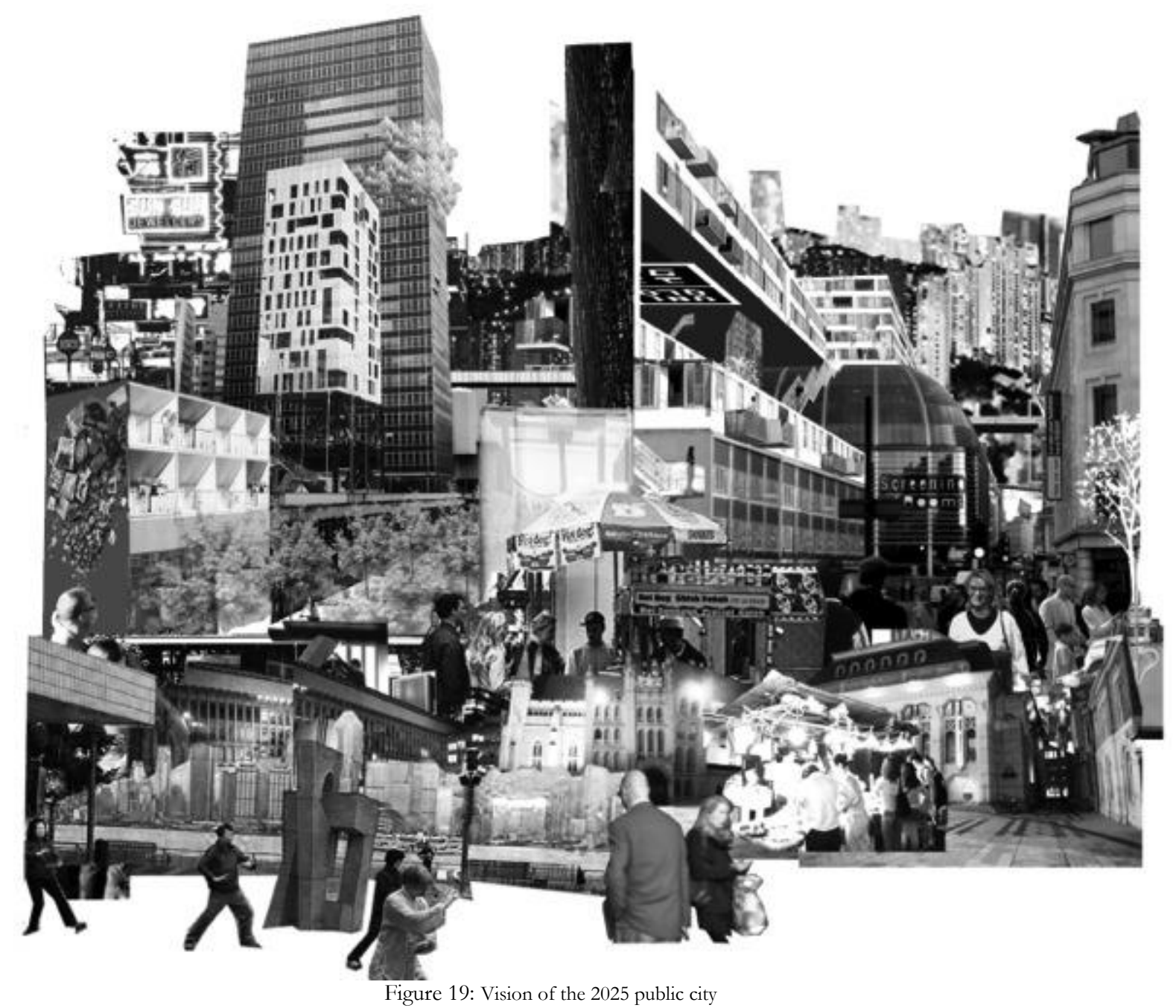

